AÜIFD Cilt XLIII (2002) Sayı 2 s. 315-353

\title{
Din Görevlilerine Mûsikî Eğitimi Verilmesi Hakkında Örnek Bir Metot
}

\author{
Bayram AKDOĞAN \\ Yrd. Doç. Dr., Ankara Üniversitesi Ilâhiyat Fakültesi \\ e-mail:akdogan@divinity.ankara.edu.tr
}

An Model Method on Training of the music Education of Religious Man. One of the field on which the music has effected is Religious Forms. Among these forms Adhan (Call to prayer) has the most important place in the Religious Music. Nowadays it has been mostly speculated on the Adhan by the laymen and the people. We also dealt with the this subject by writing an essay on it. And in this article, we have discussed on the problems which are related to Adhan and some other religious forms. We suggested that some solutions about them. In brief, we belive that all the students in the education institutions and schools on religious fields need to be given these training. As a result, we wish also this article will be useful for everyone who are interested.

Key Words: Religious Music, Religious Music Forms, Adhan, Education of religious music.

\section{Giriş}

Mûsikînin etkili olduğu alanlardan birisi de dinî formlardır. Dinî formlar içerisinde özellikle ezanların halka açık ve yüksek sesle okunduğunu göz önünde bulundurursak, böyle önemli bir çağrının ve İlâhî dâvetin, 
mükemmel bir şekilde icra edilmesi gerektiği, toplumun her kesimi tarafından bilinmektedir. Günümüzde çeşitli televizyon programlannda ve basında bu konu üzerinde çokça konuşulmuştur. Ezan ve dinî formlar, Türk Din Mûsikîsi'nin konusunu teşkil ettiğinden, bu alandaki aksaklıkları gidermek için, ilerde yapılacak çalışmalara da ışık tutacağını düşünerek örnek bir metot ortaya koymamızın yararlı olacağı kanaatine vardık. Çalışmamız başlı başına bir metot değildir, aynı zamanda bu alandaki eksiklikleri dile getirip acilen çözümünü öneren bir araştırmadır. Câmi içi mûsikîsi formlarından olan Kur'ân'ın güzel sesle okunması, Kâmet, Mahfel Sürmesi, Tekbîr, Salât vs. da ele alınacak olursa, mûsikînin dinî formlardaki önemi ve gereği daha açık bir şekilde ortaya çıkar. Bu sebeple, Türkiye'de mevcut din görevlilerinin, din görevlisi eğitimi veren okullarda okuyan ve istikbalin din görevlisi olacak olan adayların ciddî bir müzik eğitimine tâbi tutulmalarının lüzumuna inanıoruz.

\section{Metot Hakkında}

Bu metotta eski nazanî bilgileri daha değişik üslûpla öğretme, müzikle ilgili araç ve gereçlerin çoğalması sebebiyle daha kaliteli ve daha çok efektlere sahip ses cihazlarıyla çalışma, zaman kaybına sebep olacak olan her türlü israfı bırakarak, daha gerçekçi bir metotla çalışma anlayışını hâkim kılmak istiyoruz. Bunun için de başta öğretmen durumunda olan kişilerin bu konuda gerçekçi olmalarını istiyoruz. Ondan sonra öğrencilerin durumu, kullanılacak araç ve gereçlerin kalitesi gelmektedir.

Şimdi, konumuza girmeden önce, dinî mûsikînin ne olduğu konusunda kısaca bilgi verelim.

\section{Bir Kavram Olarak Dinî Mûsikî ve Mahiyeti}

Her hangi bir dinde, ibadet amacıyla yapılan bir takım sesli okuyuşlarda güzel ses unsurunun tatbik edilmesine kısaca dinî mûsikî diyebiliriz.

Dinî Mûsikî'nin insanlık tarihi boyunca uygulandığı bilinmektedir. En ilkel dinlerde ve kabilelerde bile mûsikînin dinî amaçlı olarak kullanıldığ bir vakıadır. Eski Türk dini çerçevesinde, muayyen zamanlarda bazı dinî törenler yapıldığı, toy'larda, yahut ölenin ardından tertiplenen yuğ'larda dinî mahiyette mûsikîye yer verildiği bilinmekte, ayrıca Çin kaynaklarında, Hunlar'ın dinî yaşantıları anlatılırken, Türklerin Çin Seddi'ni aşan süvârilerini, davula benzer müzik âletleriyle savaşa teşvik ettikleri nakledilmektedir. ${ }^{1}$

1. İsmail Hakkı Özkan, Türk Mûsikîsi Nazariyatt ve Usûlleri Kudüm Velveleleri, Ötüken Neşriyat, 2. bsk., Istanbul, 1987, s. 17. 
Tarihin yazılmaya başlandığı en eski devirlerden ve en ilkel kabilelerden günümüze gelinceye kadar hemen hemen her toplumda güzel ses veya müzik âletleri dinî amaçlı olarak kullanılmıştır. Hz. Muhammed'in (s.a.s.) getirdiği şeriattan önceki semâvî dinlerde de güzel ses unsuru gündemdeydi. Davûd (a.s.) sesinin güzelliği hakkında, gerek Kur'ân-ı Kerim'de, gerek hadîs-i şerîflerde çok bahsedilmektedir. En ilkel kabilelerde olduğu gibi günümüzde de mûsikî direkt olarak ibâdet amacıyla yahut da ibâdetlere şevk veren yardımcı bir araç olarak kullanılmaktadır. Dinî mûsikî, Hristiyanlıkta kilisede âyin esnasında orgla icrâ edilirken, câmilerde sesle icrâ edilen vokal müziğe döner. Afrika'da ve dünyanın bazı yerlerinde hâlen ilkellikten kurtulamamış kabilelerde de müzik bizâtihi ibadet olarak yapılır. Kısaca, her hâlükârda müzik ya ibadetin kendisi veya ibadet esnasında insana şevk veren önemli bir araç olarak kullanılmaya devam etmektedir.

İslâm toplumunda, mûsikînin ibadetlerde Müslümanlara şevk ve heyecan vermesi için ilk faaliyetler $\mathrm{Hz}$. Peygamber döneminde, Kur'ân kıraati ve ezan okuma gibi dinî formlarda kendini göstermektedir. Bu dönemde, saz ve söz mûsikîsi her ikisi de kullanılmıs, hatta yerine göre tavsiye edilmiştir. Peygamberimiz bulunduğu meclislerde sesi güzel olanlara Kur'ân ve ezan okutur, anlam itibariyle etkileyici mânâlara sahip olan Kur'ân'ı özellikle Ebû Musa'ya okutur, ${ }^{2}$ cemaatin şevkini artırır ve kendisi de coşardı. Ezan saati geldiğinde Bilâl-i Habeşî̀ ye "Ya Bilâl haydi bizi ferahlandtr"3 buyurur, ve onun güzel sesiyle Müslümanlar namaza şevkle koşarlardı. Ayrıca din dışı formlarda $\mathrm{Hz}$. Peygamber sazlı mûsikî içerisinde zikredilen ve def eşliğinde çalınan parçaları reddetmez, bilakis kendi arzusuyla dinlerdi. ${ }^{4}$ Hatta ashâbı kirâmdan ileri gelen bazı mü'minler bu

2. Peygamberimiz bir defasinda Ebû Musa'ya Kur'ân okutmuş ve güzel sesle okunan Kur'ân'ı dinledikten sonra: "Ey Ebû Mûsa! Gerçekten sana, Dâvud ailesine verilen mizmarlardan bir mizmar verilmiştir." buyurarak, memnuniyetini izhar etmiş ve Ebû Mûsa'yı övmủştür (Ebû Abdillâh b. İsmail el-Buhârî, Sahîhu'l-Buhârî, el-Fedâilü'lKur'ân: 31, c. VI, s. 112, İstanbul, 1979; Ebu'1-Hüscyn Müslim b. El-Haccâc el-Kuşeyr̂, Sahih-i Müslim, es-Salâtü'l-Müsâfirîn: 235-236, c. I, s. 546, Beyrut, Tarihsiz.

3. Süleyman b. Eş'as es-Sicistânî Ebû Dâvud, Sünen-i Ebî Dâvud, Edeb, Hadîs: 4985- 4986, IV/ 296-297, Dâru İhyâi't- Türâsi'l-Arabî, Beyrut, Tarihsiz.

4. Buhârî ve Müslim'in $\mathrm{Hz}$. Aişe (r.a.)'den ittifakla rivâyet ettikleri bir hadîs-i şerîfte $\mathbf{H z}$. Aişe şöyle anlatıyor: (Babam) Hz. Ebû Bekr bize geldi, benim yanımda, Ensar'ın Büas harbindeki karşılıklı atışmaların sözleriyle terennüm eden iki câriye vardı. Resûlullah (s.a.s.) de kaftanına bürünmüş yatıyordu. Ebû Bekr: "Resûlullah'ın evinde şeytanın mizmarı ne gezer" diye beni azarladı. Bu olay bayram gününde cereyan etmişti. Peygamber (s.a.s.) yüzünü açtı ve "Ey Ebû Bekr, her milletin bir bayramı var, bugün de bizim bayramımızdır." buyurdu (el-Buhârî, a.g.e., Îdeyn: 3, c. II, s. 3, İ stanbul, 1979; Ebû Abdillâh Muhammed b. Yezîd el-Kazvînî İbn Mâce, Sünen-i Ibn Mâce, Nikâh: 21, Hadîs: 1898, c. I, s. 612, M.F.A. Bâki neşri, Beyrut, 1975. 
hareketlerin Resûlullah'ın huzurunda yapılmasını saygısızlık ve ayıp olarak değerlendirdiğinde, Resûlullah (s.a.s.) derhal müdahale eder ve dine aykırı bir durum söz konusu olmadıkça bunların çalmalarına ve şarkı okumalarına devam etmelerini isterdi..$^{5}$

Resûlullah (s.a.s.) mûsikînin (vokal müzik) dinî amaçlı olarak kullanılmasını teşvik ettiği gibi, din dışı meclislerde de sazlı mûsîkî cinsinden sayılan ve defle bir takım şiirlerin şarkı gibi çalınıp söylenişini dinlemiş, hatta bir defasında dügünden dönen $\mathrm{Hz}$. Aişe'ye, düğünde "def" veya "oyun eğlence" var mıydı, keşke def veya eğlence olsayd ${ }^{6}$ diye temennide bulunmuştur.

Hz. Peygamber'in güzîde ashabından bazılanı, ud ve benzeri müzik âletini çalan câriyeleri dinler ve bunları haram saymazlardı. Bazen bu mûsikî meşkleri, ashâbı kirâm arasında tartışmalara sebep olurdu ancak, sonunda bu tartı̧̧malar birbirlerini ikna etmeleriyle son bulurdu. Çünkü bu konuda yasaklayıcı ve kesin bir emir yoktu ve bu tip davranışlarda asıl olan niyetti.?

5. Hz. Aişe (r.a.) anlatıyor: "Ashab-1 Resûl şiirler okuyorlardı, Resûlullah da onları tebessümle karşıllyordu. Sahabeden hiçbir kimseden, güzel ses ve ölçülü nał̆me olması nedeniyle şiiri inkâr eden bir haber nakledilmemiş, bilakis zaman zaman develeri yürưttmek, bazen de zevk için şiiri kullandıklan haber verilmiştir." (Ebû İsa, Muhammed b. İsa b. Sevre et-Tirmizî, Sünenü't-Tirmizî, Edeb: 70, Hadîs: 2850, c.V, s. 140, Beyrut, Tarihsiz. Tirmizî bu hadîs için "Sahîh ve Hasen" demektedir; Ebû Abdillâh Malik b. Enes, el-Muvatta', Sefer: 93, c. I, s. 175, Dâru Ihyâi'l-Kütübi'l-Arabiyye, Beyrut, Tarihsiz; Ebû Abdi'r-Rahman Ahmed b. Şuayb b. Ali el-Horasânî en-Nesâ̂, Sünenü'nNesât, Sehv: 99, c. III, s. 80-81, Beyrut, Tarihsiz).

6. Hz. Aişe'den rivâyet edilmiştir: Hz. Aişe bir defasında (yanında büyüttügü) bir kadını Ensar'dan bir adamla evlendirmişti. (Dưgünden dönen Hz. Aişe'ye) Nebî (s.a.s.) sordu: "Ya Aişe! Şüphesiz ki Ensar (kadınları mûsikî ve) eğlenceyi severler." (el-Buhân̂́, a.g.e, Kitâbu'n-Nikâh bâbu'n-nisvati'l-lâtî yuhdîne'l-mer'ete ilâ zevciha, c. IV, s. 140.) Hz. Aişe Ensar'dan akrabası olan bir kızı (câriye) evlendirmişti. Resûlullah ona sordu: "Kızı kocasına götürdünüz mü? Kızı kocasına teslim edecek ve zifafa atacak kadınlar gönderdiniz mi? Hz. Aişe, "evet" diye cevap verdi. Resûlullah: "Keşke bir de muğanniye gönderseydiniz de:

"Eteynâküm, eteynâküm, fe-hayyunâ nühayyîküm"

"Size geldik, size geldik, bizi selâmlayınız, sizi selâmlayalım" türküsünü söyleseydi. Çünkü Ensar gazel (kadın tasvir eden şiirlerin nă̈me ile okunmastnt) sever buyurdu." (Ahmed b. Hanbel, Müsned, c.I, s. 391, c.VI, s. 360, Beyrut, M. 1969/ H. 1389).

7. Âmir b. Sa'd diyor ki: "Bir düğün münasebetiyle Kuraza b. Ka'b ve Ebû Mesûd elEnsârî'nin yanına gitmiştim. Bu iki sahabenin yanlarında türkü söyleyen muğanniye kızların bulunduğunu gördüm. Dedim ki: Siz Resûlüllah'ın sahabelerisiniz, aynı zamanda Bedir Savaşı' nda bulunma faziletine ve şerefine de sahipsiniz. Buna rağmen huzurunuzda böyle isler nastl yaptliyor? Dediler ki: Istersen buyur, otur ve bizimle birlikte sen de dinle, istersen çekip git, fakat şunu bil ki, dügünde mûsikî (lehv) dinlemek için bize ruhsat verilmiştir." (Ebû Abdi'r-Rahmân b. Şuayb en-Nesâî; Sünenu Nesâi (Hâfız Celâlu'dDîn es-Suyûtô'nin Şerhi ve Imam es-Sindî'nin Hâşiyesiyle), Kitâbu'n-Nikâh, Bâbu'l-Lehv ve'l-ginâ' inde'l-ğurs, VI/135. Dâru Ihyâi't-Türâsi'l-Arabî, Beyrut, Tarihsiz). 
Emevîler döneminde işret âlemleri artınca, mûsikîyi yasaklayan bir çok hadis uydurulmuş, bu serkeşliğin önüne hadis uydurmakla geçilebileceği düşünülmüştür. İ̧̧ki meclisine tâbi olan mûsikînin haramlığı konusunda zaten hiçbir kimsenin itirazı yoktu. Bu arada ihtiyata binaen âlimlerden bazılan her türlü mûsikîyi haram sayarak, halkı bu konuda uyarmayı dinî bir vecîbe saymıştır.

Abbâsîlerin gerek idare ve gerekse başka milletlere karşı ılımlı tutumuyla İslâm dairesine giren Türk topluluklan mûsikî konusunda endişesiz hareket etmiştir. Hoca Ahmet Yesevî'nin bahşı, baksı veya ozan adı verilen müritleri, sazlanyla diyar diyar dolaşarak sözleri dinî irşât niteliği taşıyan bir takım mânileri sazlarıyla çalmışlar ve insanları, yeni idrak etmiş olduklan Islâm dinine, nağmelerle çağırmışlardır.

Günümüzde Türk Mûsikîsi'nin bütün formlannda olduğu gibi dinî formlarda da, mûsikî dediğimiz güzel nağmelerin uygulanması olayı son derece önemlidir. Bilhassa Müslüman olsun veya olmasın her kesimden insana günde beş defa çağrn yapan ezan formunun, lâyık olduğu bir ses düzeniyle okunması son derece önemlidir. Ezanın vakitlere göre uygun bir makam ve eğitilmiş bir sesle okunmasının, inananları câmiye davet etmede ne kadar önemi varsa, -Müslüman olmadığı halde- bu çağrnyı ister istemez günde beş defa dinleyen insanlar üzerinde de etki etmesi açısından da o kadar önemlidir. Ezanın sözlerinden bir şey anlamayan inançsız kesim üzerinde etki yapabilecek tek şey, ezanın münasip bir makam ve nağme ile okunmasidir.

Iş̧e Türkiye'de din görevlilerinin bu duygular istikametinde yetiştirilmeleri için, çeşitli seminerler veya kurslar açılarak ses eğitimine tâbi tutulmaları gerekmektedir. Hiç olmazsa câmi içi formlarında, en çok kullanılan birkaç makamı uygulayabilecek bir mûsikî bilgisinin verilmesi, sadece nazariyatla kalmayıp bunun uygulamalı olarak yapılması lazımdır. Bu işler için de ivedilikle hareket edilmesinin çok gerekli ve lüzumlu olduğu kanaatindeyiz. Bunu gerçekleştirebilmek için de, öncelikle din görevlisi yetiştiren okullarda ve kurumlarda öğretmen olarak görev yapan elemanların bu konuda hazırlanması ve bir eğitimden geçirilmesi gerekmektedir. Ne yazık ki, öğretmenler içerisinde bile hâlâ, din görevlilerinin mûsikî açısından eğitilmelerine olumlu olarak bakmayanlar mevcuttur.

Mûsikî eğitimi almış kimselerde ve onların yaptı̆̆ı çalışmalarda bir başka ahenk, bir başka "insana yakınlık" vardır. Büyük dehâların hayatını incelediğimizde, onlann aynı zamanda mûsikî veya sanatın diğer branşlanyla da yakından ilgili olduklarını görürüz. Onların çalışmalanında, ortaya koydukları eserlerde ve insanlarla olan münasebetlerinde, bir bakıma 
Allah'nn kâinatta gizlediği ahengin aksettiğine şahit oluruz. Bu Ilâhî âhengi hissetmekle insanoğlu bir huzur dünyasının kapılarının aralandığını kalbinin derinliklerinde hisseder ${ }^{8}$ Işte günümüzün din görevlisi mûsikî eğitimi almış bir kişi olarak ve güzel sesin cemaat üzerinde yapacağı tesiri bilerek bu duygularla hareket ettiği zaman çok daha başarılı olacaktır.

\section{Hadîslere Göre Dinî Mûsikî}

Dinî mûsikînin bugünkü hâline gelmesinde $\mathrm{Hz}$. Peygamber (s.a.s.)'in sünnetlerinin, sahabenin uygulamalarının, tasavvufçuların tatbikatlarının, ulemânın görüşlerinin, değişik millet ve kabilelere mensup insanların yaşadıkları bölgesel, yerel örf ve âdetlerin hepsinin ayrı ayrı etkisi olmuştur.

Peygamberimiz (s.a.s.) peygamberlik görevi dışında bir insan olarak yiyip içen, bazen gülen bazen ağlayan, bazen yatan bazen uyumayan, geçim ve rızk için çalışan, çarşıda pazarda dolaşan bir varlıktı. Bu sebeple, Allah'a isyan olmayan yerlerde oturmuş, bir takım eğlence meclislerinde bulunmuş, oralarda icrâ edilen müzikleri veya folklor hareketlerini izlemiş, insanı günün yorgunluklarından kurtanıp rahatlatacak bir takım eylemleri müşahede etmiş, bunlanın bizzat huzurunda yapılmasına ses çıkarmamıs, bunları yapanları reddetmemiş, bilakis sevincini ve mutluluğunu beyan eden sözler söylemiştir. Allah'a isyan, dinin emirlerine ters düşen hareket ve sözleri de, anında düzeltmesini bilen bir peygamber olarak, insanın fitratına ve psikolojisine uygun hareket etmiştir. Hatta bazı zamanlarda Peygamberimizin huzurunda yapılan oyun ve eğlenceleri -takvası gereğiayıp sayarak engellemeye çalışan ashabın bazı ileri gelenlerini Peygamberimiz îkaz etmiş, karışmamalarını söylemiştir. Nitekim kendi evinde def çalıp parçalar söyleyen genç kızlara engel olmak isteyen $\mathrm{Hz}$. Ebû Bekir'i îkaz ettiği gibi.

Hz. Peygamber bir defasında Beni Erfide denilen bir kabileyi ziyarete gittiğinde, Peygamberin gelişini görünce oyun eğlenceyi bırakan bu kabile halkına: "Ey Erfide oğulları, cüd eyleyin, eğlenin ki Yahudiler ve Hristiyanlar bizim dinimizde ruhsat ve serbestlik olduğunu bilsinler."9 buyurmuştur. Hz. Peygamber'in yaşadığı dönemde bunun çok daha örnekleri vardır. Şimdilik bu bilgilerle yetinerek, dinî mûsikînin İslâm dinindeki önemine geçmek istiyoruz.

8. Türk Gençliğinin Müzik Eğitimi, 27-28 Nisan 1985 Türk Kadınları Kültür Demeği'nin "Türk Gençliz̧inin Müzik Eğitimi" konulu Sempozyumu, Aytư̆ Iz’at: Açı̧̧ Konuşması, Kadıoglu Matbaası, Ankara, 1985, s. 7.

9. Ahmed b. Hanbel, el-Müsned, VI/ 116, 223. 


\section{Dinî Mûsikînin İslâm Dinindeki Yeri ve Önemi}

Dinî mûsikî denilince, daha çok ses (vokal) mûsikî akla gelir. Dinî formlar içerisinde özellikle Kur'ân'ın ve Ezan'ın güzel sesle okunması olayı bizzat $\mathrm{Hz}$. Peygamberin emirleriyle ve tavsiyeleriyledir. Konuyla ilgili hadislerden bazıları şöyledir:

"Kur'ân'ı seslerinizle süsleyiniz, çünkü güzel ses, Kur'ân'ın güzelliğini artırtr."10

"Her şeyin bir süsü vardır, Kur'ân'ın süsü de güzel sestir."1!

"Kur'ân'ı Arapların nağmeleri(okuyuş tarzı, tavır, şive)'yle okuyunuz." 12

"Kur'ân'ı nağme ile okumayan bizden değildir."13

Bunlara benzer daha bir çok hadîsi kaynaklarda bulmak mümkündür. Mûsikî dinî formlarda gerçekten bir güzellik meydana getirmekte, ibadette teslimiyeti artırmakta, insana huzur ve rahatlık bahşetmektedir.

Mûsikînin Kur'ân'da uygulanması hususu başlı başına bir konudur. Kur'ân'ın tecvit kaidelerine uyularak okunması yanında, âyetlerin ifade ettiği anlamlara göre makamlann tatbik edilmesi çok önemlidir. Çünkü, makamlar içerisinde hüzün bildiren, sevinç ve neşe ifade eden, cesaret ve şecaat veren, uyutan veya uykuyu kaçıran, miskinlik ve tembellik veren, dinamiklik ve neşat kazandıranları vardır. Kur'ân âyetleri içerisinde de zaman zaman cennetteki güzelliklerden, oradaki nimetlerden ve zevk-u safâdan bahsedilmekte, cennetliklerin yaşadıkları rahatlıklar, cehennemdekilerin çektikleri ıstıraplar anlatılmaktadır. Doğruluk ve adâletin güzelliği, haksızlığın kötülüğü, Cenâb-1 Hakk'ın yüceliği ve O'nun gücü karşısında diğer yaratıkların âcizliği belirtilmektedir. Kâfirlerin İslâm'a saldırı sözleri ve bunlara karşı Cenâb-1 Hakk'ın cevabı, öfke ve gazabı, daha nice ses tonuyla ifade edilebilecek ve makamlarla yansitılabilecek durumlar mevcuttur. Kur'ân'ın anlamını bilen bir kişi, âyetlerin ifade ettiği anlama uygun bir makamla okuyan hâfızın Kur'ân'ını dinlediği zaman son derece etkilenir. Hatta Kur'ân'ın anlamını bilmeyen halkın, Kur'ân karşısında etkilenecekleri tek şey onun mübarek lafızlarının mûsikîyle terennümü, güzel ve makamlı bir sesin iniş ve çıkışlandır. Eğer, Kur'ân'ı bazı mezhep

10. Buhânî, a.g.e., Kitâbu't-Tevhîd, bâb: 52; Ebû Dâvud, Vitir: 20 'de rivâyet etmektedir.

11. Es-Suyûtî, el-Câmiu's-Sağîr, II/125.

12. Es-Suyûtî, a.g.e., II/52. Bu hadîs Kur'ân'ın, sadece Arap tarzında okunmast anlamına gelmez. Ancak Kur'ân Arapça olduğu için, Arapça lafızlan makamlı olarak onlar gibi terennüm etmenin önemi vurgulanmaktadır $k i$, zaten bu hadisin mevsûk olmadığı söylenmektedir.

13. Ibn Mâce, a.g.e., Ikâmet: 176, Bâbun fî haseni's-savti bi'1-Kur'ân, Hadîs: 1337, c. I, s. 424; Buhânî, a.g.e., Tevhîd: 97, Bâb: 44, c. VIII, s. 209. 
taraftarlanı gibi mûsikîsiz yalın bir sesle okuyacak olursanız, bir çok dinleyicinin bunun kıraatinden mutluluk duymaları imkânsızdır.

$\mathrm{Bu}$ konumuzda, mûsikînin dinî formlar üzerindeki önemini tek tek ele alarak izah etme yoluna gitmeyeceğiz ama, çok önemli bir dinî form olan ezanda, mûsikînin önemine değinmeden de geçmek istemiyoruz.

Günde beş vakitte, sesi güzel ve makam bilen bir müezzin tarafında okunan ezanlar, inananları çekmekte, ibadet konusunda tembel olan Müslümanları uyarmakta, hatta inanmayanları bile etkilemektedir.

Burada çok önemli bir husus daha vardır ki, ezanın, tüm insanlara açık olarak yapılan bir çağnı olması, evrensel bir çağn niteliğinde olması hasebiyle -lâfızlan ve yapısı bozulmadan- ses ve mûsikî cihetiyle dünya standartlarında bir nağme ve ses güzelliğiyle okunmasının gerektiğine inanıyoruz. Önceleri sadece belli bir mahalledeki Müslümanları namaza çağırmak için kullanılan ezanın, günümüzdeki anlamı ve önemi çok daha farklıdır. Sürekli yabancı ziyaretçilerin akımına uğrayan İstanbul, Ankara ve İzmir gibi büyük şehirlerimizde ve sahil kentlerimizde, ezanın evrensel bir mesaj vermede çok önemli olduğunu düşünüyoruz. Bir diğer husus da, böyle evrensel bir çağnının parazitsiz ve çok temiz ses veren, hassas efektlere sahip amplifikatörler kullanılarak duyurulmasıdır. Günümüzde ne yazık ki, bir taraftan ezanı okuyan müezzinin sesindeki parazitler, bir yandan da kullanılan cihazların kalitesizliği, bir çok kentte ve mahallede -Müslüman olsun veya olmasın- insanları çok rahatsız etmektedir. Aynca bu ses cihazlarının kullanma şekli de çok önemlidir. Her ezan saatinde cihazdan ses çıkıyor mu? diye "fü, fü" veya mikrofona el ile vurarak "tak, tak" diye çıkarılan lüzumsuz deneme sesleri de insanları rahatsız etmektedir. Bunlara ilâveten, müezzinin mikrofonda boğaz temizleme çalışması yapması, öksürüp aksırması da eklenince konunun ciddiyeti daha açık bir şekilde ortaya çıkmaktadır. Bu hususa burada nihayet verip, ezanların insanlara verdiği duyumlardan bahsedelim.

Meselâ akşam ezanı Segâh makamıyla okunur, bu makam bir bitişin bir sonun habercisidir. Güneşin batışılla hayat sayfalarından bir yaprak daha gittiğini, nice sağ olan insanların bir akşam güneşi gibi bu dünyaya vedâ edip gittiğini hatırlatıyor ve ey insan bu geri dönüşü olmayan yolculuğa sen de adım adım yaklaşıyorsun hazır mısın? der gibi bir rûh hâliyle bizlere mesaj vermektedir. Dinî formlarda makamlan tatbik ederken, makamların vakitlere göre etkilerini göz önünde bulundurarak hareket etmelidir. Makamların vakitlere göre tesirleri çeşitli kaynaklarda bulunmaktadır. 
Makamların tesirleri hakkında Şeyh İbn Sînâ'dan ${ }^{14}$ nakledilmiştir ki, subh-1 kâzib ${ }^{15}$ vaktinde Râhevî, subh-1 sâdık vaktinde Hüseynî, güneşin iki mızrak boyu yükselmesi vaktinde Rast, kuşluk vaktinde Ebûselik, ${ }^{16}$ günün yarısında Zengüle, öğle vaktinde Uşşak, iki namaz (öğle ile ikindi) arasında Hicâzî, ikindi vaktinde Irak, güneş batarken Isfahan, akşam vaktinde Nevâ, yatsı vaktinde Büzürg, uyku vaktinde Muhâlif makamlarıyla bestelenmesi (veya okunması) gerekir. Şayet uyuyamazlarsa, aksine ısrarla bestelemeye (veya makamla söylemeye) devam ederler ve o anda Şehnâz makamıyla okunur. Çünkü, Şehnâz ile Muhâlif makamı birbirinin zıddıdır. Bu durum, nefiste bir sıkı̧̧ma meydana getirir ve uyutur. ${ }^{17}$ Buna göre bir din görevlisi makamlan bilirse ve dinî formları buna göre okursa, dinleyenler üzerinde çok daha etkili bir okuyuş tarzı ortaya koyabilir.

Ezanın öğle, ikindi, akşam ve yatsı vakitlerinde okundukları makamlara ve bu makamların özelliklerine girecek olursak, bu makalemizin birkaç katı büyüklüğe çıkacağı açıktır. Bu konuyu da burada bitirerek, nasıl bir dinî mûsikî öğretimi yapılabilir konusuna geçmek istiyoruz.

\section{Nasıl Bir Dînî Mûsikî Öğretimi?}

Konumuza başlamadan önce din görevlisinden maksat câmilerde görev yapan imam ve müezzinlerimizi, ayrıca Kur'ân kurslarında öğreticilik yapan görevlileri kastediyoruz. Öğrencilerden kastımız ise, din görevlisi yetiştiren meslek okulu öğrencileridir. Konular içerisinde, bazen bu grupların her birine öğrenci olarak tavsiyelerimiz olacaktır.

Eğitim işi bir sanattır. Müzik eğitimi ise sanat içinde bir sanattır diye düşünüyoruz. Sanat içinde bir sanat yapacak olan müzik eğitimcisinin de sanatçı bir ruha ve kişiliğe sahip olması gerekmektedir.

Müzik öğretiminin genel kuralları yanında, dinî müzik öğretiminin ayrıca bazı ekleri vardır. Dinî müzik formlarında kullanılan güfteler Arapça,

14. Makamların icrâ vakitlerine ait olan bu sözler, bir çok müellifin kitabında nakledilmiş, kimileri Ibn Sînâ'ya, kimileri Ebu Nasr el-Fârâbî'ye, bazıları da Safiyyu'd-Dîn'e izafe etmektedir ki, doğrusu da kanaatimizce budur. Çünkü makamlar XIII. yüzyıl içinde isimlendirilmişdir. Bkz. Muhammed b. Abdilhamid el-Lâdikî (888/1483'te hayatta), er-Risâletu'l-Fethiyye, Şerh ve Tahkîk: Hâşim Muhammed er-Receb, 1. bsk. Kuveyt, 1986, s. 215, Dipnot: 182.

15. Yalancı sabah, sabahleyin dogu istikametinde bir beyazlık belirir, bu geçicidir. Buna "Fecr-i Kâzib" veya "Subh-ı Kâzib" denilmektedir. Bu kaybolur, yeni bir beyazlık başlar, işte asıl sabah budur, buna da subh-1 sâdık denir.

16. Kaynaklarda Ebûselik olarak geçen bu makam Bûselik makamı olarak kısaltılmıştır. Araplar "Ebû Saîd" ismini "Bû Said" şeklinde kısa telaffuz ederler.

17. Ibn Sînâ'dan nakledildiģi söylenen bu açılamalar onun, ne eş-Sifấ' adlı eserinde ve ne de "Risâletun fi'l-Mûsîka" (er-Risâletu'l-Mulhakatu bi-Kitâbi'n-Necât) adh eserlerinde görülememiştir. 
Farsça veya bunlara bir de Türkçe'nin karışmasıyla meydana gelen Osmanlıca'dır. Özellikle dinî formlar içerisinde Kur'ân ve Ezan'ın doğru telaffuz edilebilmesi, doğru okunması olayı, bunların güzel sesle okunması meselesinden daha önce gelir. Bunun için de Tecvît ve Ta'lim dersleri almış olmak lâzımdır. Öncelikle bu dersleri almış olan kişilerin ses eğitimine geçilebilir. Şunu hiçbir zaman akıldan çıkarmamak lâzımdır ki, dinî mûsikîde ses ve müzik çok önemlidir ama; okuyucu, hiçbir zaman kelimeler ve güfte dediğimiz sözler üzerinde bağımsız olarak serbestçe dolaşma hakkına sahip değildir. Okuyucu, öncelikle Tecvit ve Ta'lîm olmak üzere bir takım kurallara bağlı kalmak zorundadır. Tecvit ve Ta'lim dersleri almamış olan şarkıcılar, makamları iyi bilseler de, ezanı ve dinî formlanı doğru icra edemezler. Bunu belirttikten sonra, şimdi de dinî mûsikî eğitimi almak isteyenlere yapmamız gereken uygulamalara geçiyoruz.

\section{I- Diyafram Nefesi Alma Çalışması}

Dînî mûsikî eğitimine tabi tutulacak din görevlilerine veya öğrencilere önce doğru nefes alma teknikleri öğretilir. İyi bir okuyuş için öncelikle psikolojik olarak hazır olmak lazımdır. Koşarak gelen veya bir olayın etkisini üzerinden atamamış olan, yahut da bedenî bir rahatsızlığı olan kişi, ruhen bir şey okumaya hazır değildir. Psikolojik hazırlıktan sonra iyi nefes almak gerekir. Bunun zıddı olan kötü bir nefesle iyi bir okuyuş gerçekleşmez. Tıpkı enstrüman çalan bir müzisyen gibi. Bir müzisyen enstrümanıyla çalmaya başlamadan önce, enstrümanın akordunu kontrol eder, bozuk teller varsa onları ayarlar. Iyi bir okuyucu da rahat okuyabilmenin yollarını araştırır. Boğazı sıkan kravat vs. varsa onları rahatsız etmeyecek ve engel olmayacak hâle getirir. Boğazda gıcıklık yapacak şeyleri giderir, kendi sesine uygun bir perde seçer ve diyafram nefesi alarak okumaya başlar.

Tabii ki iyi bir okuyuş için bol nefes gerekmektedir. Bunun için de bir takım egzersizler yapmak gerekecektir. Özellikle sporla uğraşmayan din görevlileri veya din görevlisi adaylarının en büyük problemlerinden birisi nefes darlığıdır. Sporla uğraşmama ve aşırı kilolarla birlikte nefes kapasitesinde bir daralma söz konusu olur. Bunun giderilmesinin en kolay yolu spordur ve saat tutarak nefes antrenmanı yapmaktır. Diyafram nefesi dediğimiz bir çeşit çalışmayı yapmaktır. Ciğerler nefesle doldurulur, sonra nefesi tasarruflu bir şekilde harcayarak -tıpkı bir araba lastiği veya bir balondan kaçan hafif bir hava tarzıyla tıss sesi çıkarılır ve nefesi kesmeden üflemeye devam edilir, saniye tutularak böylece çalışmak suretiyle, önceleri 15-20 saniye üflenirken, bu miktar 50 saniyeye ve 1 dakikaya çıkarılır. 
Özellikle üflemeli saz çalışmak isteyenlere yaptırılan bu egzersizler, aynı zamanda şan dersi alaçak olan kişiler için de geçerlidir.

Geniş bir nefes kapasitesiyle birlikte temiz bir ses ve gırtlağa sahip olmak gerekir. Boğazda ciddî bir rahatsızlığı olan veya ses telleri doğuştan bozuk olan kişilerin ses eğitimine tâbi tutulması anlamsızdır. Buna paralel olarak genizden okuma alışkanlığı olanlar da vardır. Bazı insanlar nedense normal konuşmalarında bile sesi hep burundan getirirler. Sesin temiz olması için ağıdan çıkarılması, bunun için de, okuma esnasında ağzın yeter derecede açık olması gerekir. Ağız yeter derecede açık olmazsa, gırtlaktan geçen ses burundan çıkar, burundan çıkan ses de net olmaz. Bu sebeple öğrencilere okuyuş esnasında ağzı açmaları tavsiye edilir. Bir müzik parçasını okurken gırtlaktan ses çıkarmaya alışmış olan din görevlisinin, hutbe ve vaazlardaki konuşma tarzı da değişir. Sözler ağızdan daha net ve berrak çıkar. Konuşması çok net olduğu için topluluk da onu zevkle ve iştiyakla dinler. Okuyacağı Kur'ân, Mevlid, Ezan vs. cemaat tarafından zevkle dinlenir.

\section{2- Iyi Bir Müzik Kulağına Sahip Olmak (Kulak Kontrolü)}

$\mathrm{Bu}$ safhada müzik eğitimine tâbi tutulacak olan öğrencilerin kulak durumu kontrol edilir. Çeşitli tonlarda ağızla veya bir enstrüman aracılığıyla çıkarılan sesleri taklit etmesi istenir. Verilen sesleri aynen alabiliyorsak, bu öğrenci iyi bir müzik kulağına sahiptir diyebiliriz. Yaş durumuna göre daha yukarı tiz veya daha aşağı pes sesleri alamıyorsak hemen öğrencinin kulağının zayıflığına hükmetmemeliyiz. Çünkü daha tiz ve pes sesler, zamanla, ses merdiveni üzerinde yapılacak çalışmalarla geliştirilebilir. Bazılarında bu hassasiyet adeta doğuştan gelmiştir ve intibak çok iyidir. Ancak çalışma yapmak suretiyle oktav olarak ses sahasını genişletme imkânı da mümkündür. Imam ve müezzinlerin verilen sesi algılayabilmekte genellikle güçlük çekmedikleri bir hakikattir, ancak ton ve makam farkı olabilmektedir. Verilen sesle hiç alâkası olmayan perdelerden okuyanları çoktur. Bu türden din görevlilerinin, bir süre ses ve makam eğitiminden geçirilmesi yararlı sonuçlar verebilir.

\section{3- Ses Merdiveninde Yürüme Çalışmaları}

İyi bir gırtlağa ve geniş bir nefes kapasitesine sahip olan bir müzik öğrencisini, ses merdiveni dediğimiz ve kalınlık incelik durumuna göre farklı olan bir sıra ses üzerinde sırayla gezdirme işlemine, ses merdiveni üzerinde yürütme denir. Öğrencilerin müzikle ilgilerine göre, ses genişliği de farklıdır. Bazı öğrenciler dört veya beş ses üzerinde gezinebilirken, bazıları iki veya 
daha fazla ses oktavına sahiptirler. Özellikle boş zamanlarında müzikle ilgilenmeyen, her hangi bir müzik parçasını söylemeyen, her hangi bir şarkıcının veya okuyucunun söylediği parçaları tekrar etmeyen bazı kişilerde ses sahası çok dardır. Çocukluktan beri böyle ilgisiz yetişen kişilerin ses merdiveni üzerinde çalışma yapmaları da çok zordur. Ancak yine de -bize göre- tam ve mükemmel olmasa da bu çeşit aksaklıklar giderilebilir kanaatindeyiz. Muhtelif câmilerde ve dinî toplantılarda din görevlilerinin okuyuşlan üzerinde yaptığımız incelemelere göre, bazı din görevlilerinin güzel sesten çok mahrum olduklan gibi, bunların ses merdiveni üzerinde ancak birkaç sesi çıkarabildikleri, dolayısıyla çok az bir ses sahasına sahip olduklannn, toplam dört veya beş sesi geçmeyen bir ses alanıyla, Kur'ân, ezan hatta -câmi görevlerinin dışında- bu yetersiz sesleriyle mevlid ve kasîde okuduklarına şahit olduk. Böyle bir görevli üzerinde bizzat yaptığımız incelemeler maalesef hayal kırıklığına uğramamıza sebep olmuştur. Toplam üç sesle ezan, Kur'ân ve bazı özel günlerde mevlid okuyan bu görevliyle bir müddet ilgilenerek kullandığı ses sayısını ancak beşe ve altıya zor çıkarabildik ki, sonunda böyle bir kimse için de büyük bir başarı olduğu kanaatine vardık. Başkentin önemli bir mahallesinde böyle yeteneksiz ve nâ-müsait bir sesle yıllarca görevde tutulan bir din görevlisi, halkı câmiden ve ibadetten soğuttuğu gibi, yakın mahalle sakinlerini de çok çirkin sesiyle günde beş defa rahatsız etmeye devam etmektedir ki, bu bizim tespit edebildiklerimizden sadece bir tanesidir. Bir de okuyucunun -erkek veya kadın olarak- mutlaka kişiliğine uygun bir ses tonu olmalıdır. Bu sebeple şimdi de insan seslerini ve sesin özelliklerini görelim:

Insan sesleri, erkek, kadın ve çocuk sesleri olmak üzere ikiye ayrlır. Erkek sesleri kalın, kadın ve çocuk sesleri de ince seslerdir.

1-Erkek sesleri üçe ayrılır.

a) Tenor: Ince erkek seslerine denir.

b) Bariton: Orta kalınlıkta erkek seslerine denir.

c) Bas: Kalın erkek seslerine denir.

2-Kadın ve çocuk sesleri üçe aynilır.

a) Soprano: Ince kadın ve çocuk seslerine denir.

b) Mezzo soprano: Orta kalınlıktaki kadın ve çocuk seslerine denir.

c) Alto: Kalın kadın seslerine denir.

Mûsikîde kullanılan sesler birbirinden süre, yükseklik, şiddet ve tını gibi özelliklerle ayrilırlar.

Süre: Sesin uzun veya kısa oluşu demektir.

Yükseklik: Sesin pes veya tiz oluşuna denir.

Şiddet: (Yeğinlik) Sesin kuvvetli ve zayıf olması demektir. 
Tını: Aynı titreşimde (frekansta) iki ses arasındaki tınlama farkına yani bu iki sesi birbirinden ayırt edebilme özelliğine denir. Bu, sesler arasındaki renk farkıdır. Bunlarla ilgili aynntılar, müzik eğitimi ile ilgili kaynaklarda bulunabilir.

\section{4- Bazı Makam Aralıklarıyla Çalışma}

Türk Mûsikîsi'nde kullanılan bütün makamların kendine özgü bir seyri vardır. Makamların aldıkları arızalar çok farklıdır. Karar ve güçlü perdeleri değişiktir. Makamların bazısı çıkıcı, bazısı inici, bazısı da hem çıkıcı ve hem de inicidir. Fakat bu saydığımız hususların öğrenciye öğretilmesi uzun zaman alacağından, kısa süreli seminer ve kurslarda başka metotlar ortaya koymak gerekmektedir. Meselâ öğrencilere öncelikle tabii seslerde gam yaptırıldıktan sonra Hicâz, Uşşâk, Rast dörtlüleri ve beşlileriyle oluşturulan makam cümleleri tekrar ettirilebilir. Daha ileri durumlarda her makam bir bütün olarak ele alınır ve genişlemeleriyle ve kararlanyla ilgili teferruatlı bilgiler verilebilir. Bu metot, pratik yoldan kısa zamanda mûsikî eğitimi vermek istediğimiz din görevlileri veya adayları içindir. Yoksa köklü bir müzik eğitimi alacak olanlar için tavsiye edeceğimiz bir metot değildir. Bizim kastımız olan öğrenciler, vaktiyle müzik eğitimi almamış, sadece orta öğretimde mecburi olan dersleri şöyle böyle geçmiş, veya müziğe ilgi duymamış, yaş itibariyle de biraz ilerlemiş olan kişilerin müzik eğitimi hakkındadır.

Bu safhada, bazı müzik kalıplarının (4'lü veya 5'li'lerin) dinî formlarda uygulanışını küçük örneklerle öğrencilere tatbik ettirmek gerekir. Öğrencilerin dimağında nağme birikimi olabilmesi için de çokça ilâhî ve örnek parçalar öğretilmelidir. Bu örnek parçalardan dinî formlara geçişler yapılmalı, belli bir makamdaki nağmeyi çeşitli dinî formlarda uygulamalı ve öğrencilerden tek tek yapmalarını istemelidir. Çekinen öğrenciler üzerine gidilmemeli fakat, sürekli hep aynı öğrencilerden tatbik etmeleri istenmemelidir. Çünkü bu durum sadece bazı öğrencilerin gelişmesine, diğerlerinin de pasif kalmasına neden olmaktadır. Yapamayan öğrenciye moral takviyesi yapmalı, kesinlikle ses veya başka cihetlerden öğrenciyi tenkit etmemeli ve gururu rencide edilmemelidir.

\section{5- Usûl Calışmalan}

Dinî mûsikî formlanından olan câmi mûsikîsinde usûl gerekmiyorsa da, dinî mûsikînin diğer formlarında usûl vardır. Bunun için dinî mûsikî eğitimi alan öğrencilerin, ileriye dönük çalışmalar için, ritim duygusunun ve alışkanlığının gelişmesi için basit usûllerle çalışmalar yapılmalıdır. Ayrıca 
dinî mûsikînin diğer formlarından tekke ve tasavvuf mûsikîsi formlarında usûl çok önemli olduğundan, hiç olmazsa basit ve küçük usûller din görevlileri veya adaylanna öğretilmelidir. Sadece bu saydığımız maddelerin uygulanmasıyla bir din görevlisi veya adayı mûsikîyi ve bunların dinî formlarda uygulanışını öğrenmiş olmaz. Bu saydığımız hususları yerine getirmekle bu alana bir giriş yapmış olunur. Bundan sonrası din görevlisinin veya adayın bu alandaki ilgisini sürdürmesine bağlıdır.

\section{6- Dinleme}

Din görevlisinin veya adayın çokça dinlemesi gerekir. Sıradan kasetleri ve nağmeleri değil, kaliteli müzikleri dinlemesi gerekir. Bundan kastımız, kaliteli okuyucular ve kaliteli kaydedilmiş müzikler ve nağmelerdir. Halk ağzıyla okunmuş veya müzik eğitimi görmemiş bir kişinin kaydedilmiş gelişi güzel nağmelerini dinlemenin bir din görevlisine, nağme itibariyle kazandıracağı bir şey yoktur. Bu bakımdan kaliteli olan şarkı, türkü, ilâhî, kasîde, na't, saz eseri, taksim, peşrev, kısaca güzel ve kaliteli olan her şeyi dinlemeli, kulaktan aldığı bazı güzel nağmeleri taklit etmeli fakat, taklidi sürekli kendine metot edinmemelidir. Başlangıçta taksim yapamayan bir sâzendenin, önce basit nağmeleri taklitle işe başladığı gibi. Sürekli güzel nağmeleri hafızada depolayan bir kişi, daha sonra bunlara kendisinden bir şeyler katmaya çalışmalıdır. Bu sebeple, bir din görevlisinin hafızasında ne kadar dinî ve lâ-dinî eser varsa, o kadar okuyuşu güzelleşir ve nağme zenginliği kazanmış olur. Din görevlilerine yönelik eğitim amaçlı, resmî ve özel şirketler tarafindan kaydedilmiş Ezan, İlâhî, Kasîde, Na't, Kur'ân-1 Kerîm, Mevlîd-i Şerîf vs. kasetleri piyasada mevcuttur. Her din görevlisinin bunlardan bir arşiv oluşturup, zaman zaman dinlemesinde yarar vardır.

Bir din görevlisi zaman zaman kendi okuyuşlarını bir kaydedici ile kaydedip dinlemeli, kendi kendisini tenkit ederek daha güzel okumaya gayret etmeli, daha net ve daha temiz ses çıkarma yollarını aramalıdır. Bir kayıt cihazı önünde okumak, psikolojik açıdan, kalabalık bir cemaat önünde okumaktan daha kolay değildir. Bu bakımdan, kayıt cihazı önünde rahatça okuma alışkanlığını elde eden bir din görevlisi, cemaat önünde çok daha rahat okuma alışkanlığını kazanmış olur.

Dinî mûsikî eğitimi içerisinde din görevlilerine ve adaylara öğretilmesi gereken önemli hususlardan birisi de dinî mûsikî formlarıdır. Şimdi de bunları kısaca açıklamaya çalışalım.

\section{Dinî Mûsikî (Formları) Çeşitleri}

Din görevlilerinin veya adayların bilmesi gereken hususlardan birisi de Dinî Mûsikî formlarıdır. Dinî Mûsikî formlarını bilmeyen bir din 
görevlisinin, bu formlardan birisini bilinçsiz olarak okuması da fazla bir şey ifade etmez. Câmideki okuma tarzıyla, bir düğün veya sünnet merasimindeki okuma tavrı birbirinden çok farklıdır. Bunların teferruatına surası geldikçe değinilecektir.

Dinî mûsikî formları Câmi mûsikîsi ve Tekke (Tasavvuf) mûsikîsi olmak üzere ikiye ayrilır

\section{A- CÂMí MÛSİKîsí}

1- Bestesiz Olan Câmi Mûsikîsi Formlan

a- Kur'ân-ı Kerîm

b- Ezan

c- Kâmet ve Cumhûr Müezzinliği

d- Hutbe

e- Mevlîd

2- Besteli Olan Câmi Mûsikîsi Formlanı
a- İlâhî
b- Salât
ba- Cuma Salâtı
bb- Bayram Salâtı
bc- Cenâze Salâtı
bd- Sabah Salâtı
be- Salât-ı Ümmiye
c- Tevşîh
d- Tesbîh
e- Mahfel Sürmesi
f- Temcîd ve Münâcaat
g- Na't
h- Tekbîr
i- Tardiyye
k- Mîrâciye

\section{B- TEKKE (Tasavvuf) MÛSİKîsí}

a- Tekke (Tasavvuf) Mûsikîsinin Bölümleri

1- Mevlevî Mûsikîsi

2- Bektâşî Mûsikîsi

3- Kâdinî, Celvetî ve Gülşenî Mûsikîsi

b- Tekke (Tasavvuf) Mûsikîsi Formları

ba- Mevlevî âyini

bb- Durak 


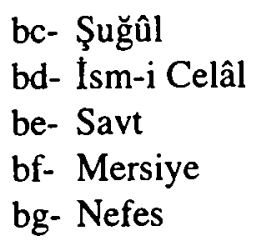
istiyoruz.

\section{A- CÂMİ MÛ́SİKîsí}

\section{1- Bestesiz Olan Câmi Mûsikîsi Formları}

Bestesiz olan Câmi Mûsikîsi formlanndan birincisi Kur'ân-1 Kerîm'dir.

\section{a) Kur'ân-ı Kerîm}

Kur'ân-ı Kerîm edebî yönüyle de eşsiz bir kitap olduğu gibi, âyetlerinin sıralanışında ve durak yerlerinde göstermiş olduğu ilâhî mûsikî de okuyan ve dinleyenlerde yüce duygular meydana getirmektedir.

Kur'ân-1 Kerîm'i okurken, tecvîd ve tertîle riâyet etmekle birlikte, onu güzel sesle okumak da Islâm' in emridir. Kur'ân' in dinlenmesinde mûsikînin önemli bir yeri vardır. Mûsikî Kur'ân'ı dinlemeye sevk eden önemli bir etkendir. Güzel ses, Kur'ân'ın güzelliğini artırır. Tegannî, Kur'ân kelimelerindeki yưice mânâlan rûha duyurmaya hizmet etmesi açısından rûhî bir kıymete sahiptir. ${ }^{18}$

Peygamberimiz (S.A.S), Kur'ân'ı ashaptan güzel sesli kişilere okutturur, dinler ve güzel sesle okunmasını emrederdi. Hadîs-i şerîflerde:

"Allah hiçbir şeyi, Peygamber'in Kur'ân't güzel sesle (veya yüksek sesle) okuyuşunu dinlediği gibi dinlememiştir."19

"Kur'ân'ı seslerinizle süsleyiniz. Muhakkak ki güzel ses, Kur'ân'a güzellik katar."20 buyurulmuştur. Bu konuda daha başka hadisler de mevcuttur.

Kur'ân-1 Kerîm bestesiz olduğu için, doğaçlama beste ile usûle bağlı olmaksızın okunur. Buradaki usûl, mûsikîdeki ölçüdür. Kur'ân-1 Kerîm bestesizdir. Tecvîde ve tertîle riâyet etmek şartı ile hemen hemen her makamla okunabilir. Özellikle anlamını bilen bir hafız tarafından makamla okunduğu zaman, gereken yerlerde sesin yükseltilmesi veya alçaltılmasıyla, dua ve yakarış bildiren yerlerde uygun bir ses tonunun seçilmesi, kâfirlere

18. Ismâil Karaçam, Kur'ân-ı Kerîm'in Faziletleri ve Okunma Kaideleri, Irfan Matbaası, Istanbul, 1976, s. 90.

19. Buhârî, es-Sahîh, Tevhîd: 97, Bâb: 52, c. VIII, s. 214.

20. Buhârî,a.g.e, Tevhîd: 52. Ebû Dâvud, es-Sünen, Vitir: 20. 
azabı bildiren yerlerde ve Hakk'ın beyan edildiği âyetlerde sesin yükseltilmesi gibi hususlara riâyet edildiğinde, dinleyenlerde llâhî bir tesir meydana getirir. Kur'ân-1 Kerîm'in güzel okunabilmesi, irticâlî beste kabiliyetini gerektirir. Ayrıca iyi bir üstattan Kur'ân ta'lîmi görmüş olmak, makamlara ve sese hâkim olabilmek, iyi bir okuyuş için gereklidir.

\section{b) Ezan}

Ezan, bildirme demektir. Ezan okuyana müezzin denilir. Cuma namazına ve beş vakit namaza dâvet için okunur. Hicretin birinci veya ikinci yılında mü'minlere namaz vaktini ilân etmede en uygun tarz olarak ezan tespit edilmiştir. Ashaptan Abdullah b. Zeyd adındaki şahıs, rüyasında bir adamı câmi damından Müslümanlan namaza çağırırken gördüğünü söyledi. Hz. Ömer, namazı ilân için bu usûlü tavsiye edince, orada bulunanlar bu fikre katıldılar ve Peygamberimizin emri ile ezan şekli böylece tayin edilmiş oldu. Bundan sonra Habeşli Bilâl ezanı böyle okudu. ${ }^{21}$

Sünnî Müslümanlara göre ezan yedi cümleden oluşur:

1- Allahu ekber (4 defa) (Allah en büyüktür).

2- Eşhedü en lâilâhe illallah (2 defa) (Şahadet ederim ki Allah'tan başka tapılacak yoktur).

3- Eşhedü enne Muhammeden Resûlullah (2 defa) (Şahadet ederim ki Muhammed Allah'ın elçisidir).

4- Hayya ale's-salâh ( 2 defa) (Namaza gelin).

5- Hayya ale'l-felâh (2 defa) (Kurtuluşa gelin).

6- Allahu ekber (2 defa).

7- Lâilâhe illallah (1 defa) (Allah'tan başka tapacak yoktur).

Sabah ezanında, "hayya ale'l-felâh" tan sonra "namaz uykudan hayırlıdır" anlamına gelen "es-salâtü hayrun mine'n-nevm" ilâve edilir.

Şiîler, "hayya ale'l-felâh" tan sonra "işlerin en hayırlısına geliniz" mânâsında "hayya alâ hayri'l-amel" ilâve ederler.

Ezanın okunması için muayyen bir makam yoktur. Kelimelerin telâffuzunu bozmamak şartıyla istenilen makam tatbik edilebilir.

Ezan okurken zâhidâne bir tavır takınmalıdır. Lüzumsuz uzatmalar, gereksiz nağmeler yaparak ezan sözlerini tahrif ve tağyir etmemelidir. Bazı müezzinlerin makam gösterme hevesiyle ezanı çığırından çıkardıklanını üzüntüyle müşahede ediyoruz. Ezan, içten gelerek ve doğaçlama olarak okunduğu için, okuyan kişinin sesi güzel ve makam bilgisi de olursa, ezan çok daha tesirli olur. 
Sünnî mezheplerin üçünde ezanı makamla okumak câizdir. Hanbelîler ve Vehhâbîler ezanı makamla okumayı uygun görmemiş ve yasaklamışlardır. ${ }^{22}$

Memleketimizde ezanların okunuşunda genellikle şu makamlar tatbik edilmektedir:

Sabah ezan1 : Sabâ ve Hüseynî,

Öğle ezanı : Rast ve Hicaz,

İkindi ezanı : Rast, Hicâz ve Uş̧̧âk,

Akşam ezanı : Segâh,

Yatsı ezanı : Rast, Hicâz, Beyâtî ve Uşşâk.

İyi bir ezan okuyabilmek için bazı hususlara riayet etmek gerekir ki, bunları şöyle sıralayabiliriz:

a- Yeterli makam ve mûsikî bilgisine sahip olmak.

b- Diyafram nefesi almak ve nefesi çok hesaplı kullanmak.

c- Ezan kelimelerini açık ve net okumak, gereksiz uzatma ve ağızda yuvarlama yapmadan okumak.

d- Ezan okumak için güzel bir sese sahip olmak gerekir. Bunun için de gerekirse biraz ses ve şan eğitimi almalıdır.

Ezan konusunda bir hususa daha değinmek istiyoruz şöyle ki, bazı özel gün ve zamanlarda, iklim ve çevre şartlarını da göz önünde bulundurarak, ezanları daha fazla uzatma veya kısaltma yönüne gidilmelidir. Bilhassa Cuma namazlarında, öğle, yatsı ve sabah namazlarında ezanları biraz daha uzun okumalı, cenâze namazı kılınacak veya dinî bir program icrâ edilecek olan câmilerde, daha çok cemaatin katılabilmesini sağlamak amacıyla ezanların, ifrata kaçmadan uzun okunmasında yarar vardır. Tabiî âfet, olağanüstü günler, sıkıntı ve stresli zamanlarda, ikindi ve akşam namazlarında ezanları kısa okumak daha uygundur.

\section{c) Kâmet ve Cumhur Müezzinliği}

Kâmet, dikilmek, ayak üzerinde kalmak, başlamak anlamlarına gelir. Farz namazlardan önce, ezan sözlerinin daha hızlı okunarak"hayya ale'lfelah" tan sonra iki defa "kad kâmeti's-salâh"23 okunmasıdır. Buna kâmet getirmek denir. Gerek kâmetin getirilmesinde ve gerekse imâmın selâm verişinden sonra okunan tesbîhlerde güzel sesin önemli rolü vardır. Bu dua ve tesbîhlerin okunması da irticâlî (doğaçlama) beste ile yapılmaktadır. Bu görevi, cemaatten her hangi birisi yapabilirde de, Arapça sözlerin doğru telaffuz edilmesi, dinleyenlere ibadet şevki vermesi, mü'minleri tevâzû ve

22. Islâm Ansiklopedisi, aynı yer.

23. "Şüphesiz namaz başladı" anlamına gelmcktedir. 
huşûya sevk etmesi açısından, bu görevin mûsikî bilen bir müezzin tarafından yapılması çok daha güzel olmaktadır.

Cumhûr müezzinliği, müezzin kadroları kabarık olan büyük camilerde, bütün müezzinlerin iştirakiyle namazdan önce ve sonra icrâ edilen mûsikîye verilen isimdir. Bir câmideki müezzinlerin en ehliyetlisi ve kıdemlisi müezzin-başı olur, diğerleri ona tâbidir. Büyük câmilerde namaz esnasında, imamın rükû ve secde için okuyacağı tekbirler -hoparlör bulunmadığındauzakta bulunan ve aynı namaz için aynı imâma uymuş olan cemaat tarafından duyulamayacağı ve görme özürlülerin de katılamayacakları düşünülerek, müezzinler tarafından tekbîrler tekrar edilir ki, buna "tekbîr alma" denir. Diğer dualar, tesbîhler, âyete'l-kürsî'nin okunması, teravih namazlarında aralarda okunan salât-ı ümmiyye veya ramazan ilâhîleri, bu müezzin kadrosu tarafından ağız birliği ile icrâ edildiği için, câmi içinde icrâ edilen dinî mûsikînin bu kısmına cumhûr müezzinliği adı verilmektedir.

\section{d) Hutbe}

Cuma ve Bayram namazlarıyla, yılın bazı günlerinde ve olağanüstü durumlarda, câmide minber üstünde yapılan konuşmaya "hutbe", konuşmayı yapan kişiye de "hatip" denir. Câmilerde mihrabın sağ tarafında bulunan ve merdivenle çıkılan bir yer vardır ki minber denilen bu kısmın en yukan kısmı $\mathrm{Hz}$. Peygamberimize hürmeten kapatılmış ve genellikle camilerde üzeri kubbeli yapılarak en üst kısma çıkılması engellenmiştir. Peygamberimiz zamanında bugünkü şekliyle minber yoktu. Yüksekçe bir kütüğün üzerine çıkar ve hutbesini öyle okurdu.

Rivâyete göre hutbeyi minber üzerinde ilk okuyan zat, Mervan b. Hakem'dir. ${ }^{24}$ Sonraları yapılan minberlerde Peygamberimizin hutbe okurken onun bulunduğu yükseklikte bulunmamak ve ona hürmet etmek için minberin en üst kısmı kapatılmış, ondan sonra dört halifenin de birbirlerine hürmeten ayrı ayrı basamaklarda hutbelerini okudukları rivâyet edilmektedir. Çoğu zaman yukarıdaki basamakları boş bırakmak için aşağıdan yedi basamak çıkılır. Fakat basamak adedi az olan minberlerde bu hususa riayet edilmemektedir.

Hutbede ağırlıklı olan kısım konuşma (hitâbet) kısmıdır. Konuşur gibi okunduğundan her hangi bir makam uygulama gerekmez. Memleketimizde bölgelere göre çeşitli hutbe okuma şekilleri vardır. Bazıları birinci ve ikinci hutbenin baş tarafındaki hamdele ve salvele ve duaları sesli ve makamlı okurlar. Özellikle ikinci hutbe denilen kısmı Kur'ân'ı güzel sesle okudukları

24. İslâm Ansiklopedisi, M.E.B, c. V, I. Kısım, s. 618. 
gibi makamlı okurlar. Doğrusu şudur ki; hutbe adından da anlaşılacağı üzere cemaate karşı yapılan bir konuşma ve bir mev'izadır. Bunun düz (makamsız) ve konuşur gibi tok bir sesle okunması daha uygun olur. Duaların da aynı şekilde yapılması daha güzel olur. Ancak hutbenin sonunda okunan "inna'llahe ye'muru bi'l-adli ve'l-ihsâni ve îtâizi'l-kurbâ ve yenhâ ani'l-fahşâi ve'lmünkeri ve'l-bağyi yaizuküm lealleküm tezekkerûn"25 âyetinin makamlı olarak okunmasi güzel olur. Hatta Cuma namazında hutbede, hatibin bu ayeti okurken vereceği ses ve makam, müezzinin aynı makamla kâmeti okumasına ve dolayısıyla hatibin aynı makamla namazı kıldırmasına neden olacağı için uygun bir makam seçmek, fazla tiz ve pes makamlardan giriş yapmamak gerekir.

Bayram hutbelerinde de aynı usûlü takip etmek yerinde bir hareket olur. Hitabetle ilgili kısımlar ister Arapça, isterse Türkçe olsun mutlaka konuşmada kullanılan ses tonuyla olmalıdır.

\section{e) Mevlid}

"Mevlîd", "doğum zamanı" demektir. İslâm literatüründe bu kelime ile doğumların en yücesi olan Peygamberimiz Hz. Muhammed'in bu âleme teşrifleri, doğduğu gün, doğum yeri ve doğum günü münasebetiyle yapılan anma merasimi anlaşılır.

Çeşitli İslâm ülkelerinde, Hz. Muhammed'in doğumunu konu alan mevlîdler yazılmıştır. Memleketimizde de bu tipte çalışmalar yapılmış fakat bu sahada en çok tutulan ve okunan mevlîd, Süleyman Çelebî'nin yazmı̧ olduğu "Vesîletü'n-Necât"26 adını verdiği mevlîdidir. Türk Edebiyatı'nın şaheserlerinden olan bu eser, mesnevî şeklinde yazılmış, samimi ve uzun bir şiirdir. Süleyman Çelebi bu mevlidi XV. Yüzyılın ilk yıllarında kaleme almıştur.

Mevlîd, çeşitli sebeplerle okutturulmaktadır. Doğum, ölüm, evlenme, sünnet, şahsî ve millî sevinç nedenleriyle, ölmüşlerin ruhlannı şâd etmek için mevlîd okutmak sevap sayılmaktadır.

Mevlîd, vaktiyle bestekârlarca usûle bağlı olarak bestelenmişse de, XIX. Yüzyıl ortalarında ve sonlarında bu besteler unutulmuştur. Bugün mevlîd, mevlithânlar tarafından doğaçlama (irticâlî) beste ile okunmaktadır ${ }^{27}$

Önceleri tamamı okunan mevlîd'in, bugün sadece belli bahirleri okunmaktadır. Mevlid şu kısımlardan meydana gelmektedir:

25. Nahl Sûresi: $16 / 90$.

26. "Kurtuluş vesîlesi" anlamına gelmektedir.

27. Yılmaz Öztuna, Türk Musikisi Ansiklopedisi, Il/29, M.E.Basımevi, Istanbul, 1974. İslâm Ansiklopedisi, M.E.B. VIII/171. 
1- "Allah âdın" bahri. Mevlîd'in ilk kısmıdır. Cenâb-ı Hakk'ın yüceliğinden ve onu zikretmenin fazîletinden bahseder. Bu kısım genellikle Sabâ, Uşşâk ve Hüzzâm makamlarından birisiyle okunursa da, genellikle mevlîd'e sabâ makamı ile başlamak âdet olmuştur. Bu kısım Hüseynî veya Uşşâk makamı ile bitirilir.

2- Velâdet bahri. Bu kısımda Peygamberimizin dogumu ve o esnadaki harikulâde olaylar anlatılır. Bu kısma genellikle Rast makamından girilir, daha sonra Uşşâk ve Hüzzâm gibi makamlara geçki yapilır.

3- "Merhabâ" bahri. "Yaratılmış cümle oldu şâdümân" diye başlayan bu kısımda $\mathrm{Hz}$. Muhammed'in doğumundan duyulan sevinç ve O'nun âlemlere rahmet oluşundan bahsedilir. Bu kısmı son zamanlarda mevlithânlar -mevlîd programı fazla uzamasın diyeokumamaktadırlar. Bu kısım da Hicâz ve Uşşâk makamıyla okunmaktadır.

4- Mîrâc bahri. Burada Peygamberimizin "Isrâ ve Mîrâc" olayı anlatılmaktadır. "Söyleşirken Cebrâil ile kelâm" diye başlayan bu kısım, "Hak Teâlâ'dan erişti bir nida" beytinden itibaren ikiye ayrılır. Bazen her iki bölüm de bir kişi tarafından okunmaktadır. Uşşâk makamıyla başlanan ilk kısım, Hicâz makamıyla biterken; ikinci kısma tiz Uşşâk makamıyla girilir, Sabâ, Hüzzâm ve Hüseynî olmak üzere çeşitli geçkiler yapilır.

5- Dua bahri. "Yâ ilâhî" diye başlayan bu bahir çeşitli makamlarda okunmakta ise de, Hüseynî makamında niyâz şeklinde okunması güzeldir. Isminden de anlaşılacağı üzere, bu kısımda Cenâb-1 Hakk'a yalvarış ve yakarışta bulunulur, O'ndan günâhların bağışlanması istenir.

Mevlîd bahirleri arasında uygun makamlarda ilâhîler okumak, aşr-1 şerifler kıraat etmek ve çokça salât-ü selâm getirmek âdet haline gelmiştir. Mevlîd sonunda yine Kur'ân-1 Kerîm'den bir aşir okunur ve dua edilerek mevlîd merâsimi sona erer.

\section{2- Besteli Olan Câmi Mûsikîsi Formları}

\section{a) İlâhî}

Ilâhî, Arapça bir kelime olup, "Allah'a ait" demektir. Dinî ve tasavvufî duygulan dile getirmek için, Allah ve Peygamber aşkıyla veya din ve tarîkat büyüklerinin meziyetlerini dile getirmek amacıyla, hece vezni ile yazılmış ve 
çeşitli makamlardan kendine mahsus bir tavırla bestelenmiş bir çeşit Türkçe manzûm eserlerdir. ${ }^{28}$

Ilâhîlere bir çeşit dinsel şarkı da denebilirse de şarkılara benzememektedir. Bunların kendilerine mahsus tavırları vardır. İlâhîyi şarkı tavrından kurtarmak için bu hususa çok dikkat etmek gerekir. ${ }^{29}$ İlâhîler zâhidâne ve itaatkâr bir tavırla, Allah'a teslim olmuş bir hâlet-i rûhiyeye sahip olarak okunur.

İlâhîler bir veya birkaç kişiyle birlikte câmi, tekke vb. ibâdet meclisleri, mevlîd merasiminde ve terâvîh namazı aralarında ve çeşitli dinî toplantılarda okunur.

İlâhî, koro halinde okunmak için bestelenmişse "Cumhûr İlâhî" adını alır. Hz. Peygamberi övüyorsa "Na't", ilâhî Arap̧̧a ise "Şuğl", Bektâşîlere aitse "Nefes", Durak Evferi ile bestelenmişse "Durak", Peygamberimizin sıfatlarını söylüyorsa "Tevşîh" gibi isimler alır. ${ }^{30}$ Bunların her biri sırası gelince izah edilecektir.

\section{b) Salât}

Salât, Arapça bir kelimedir. Lügatte "dua" ve özellikle "namaz" anlamlarına gelmektedir. "Salât" ismi, Peygamberimiz Hz. Muhammed'e, Allah Teâlâ'dan rahmet ve selâm duasını içine alan eserlere verilmiştir. Sözleri Arapça'dır. Nağmeleri çeşitli makamlardan yapılır ve -salât-ı ümmiyye hâriç- Durak Evferi usûlüyle ölçülürler. Na't ve durak'tan farkı, sadece Peygamberimize salât ve selâmı açıklamış olmalanıdır, hareketleri gayet ağırcadır ${ }^{31}$

Türk Mûsikîsinde salât, Tasavvuf Mûsikîsi'nin dışında olup, Dinî Mûsikî'nin besteli olan Câmi Mûsikîsi formuna girmektedir. Cuma Salâtı, Bayram Salâtı, Cenâze Salâtı, Sabah Salâtı ve Salâtı Ümmiye olmak üzere çeşitleri vardır.

ba- Cuma Salatı: Cuma günleri, ezandan bir müddet önce mü'minlere Cuma namazı vaktinin yaklaştı̆̆ını hatırlatmak ve bu vesileyle Peygamberimize salât ve selâm getirmek suretiyle sevap kazanmak amaciyla okunur. Salât'da okunan sözler şöyledir:

28. Öztuna, a.g.e., I/296; İsmâil Hakkı Özkan, Türk Mûsikîsi Nazariyatt ve Usûlleri, Ötüken Yay., İstanbul, 1987, s. 83; M. Ekrem Karadeniz, Türk Mûsikisinin Nazariye ve Esasları, Türkiye İş Bankası Kültür Yay., No:238, Ankara, Tarihsiz, s. 166.

29. Karadeniz, a.g.e., aynı yer.

30. Öztuna, a.g.e., $\mathrm{I} / 297$.

31. Dr. Suphi Ezgi; Amelî ve Nazarî Türk Mûsikîsi, III/ 63, Istanbul Konservatuan Yayını, İstanbul, 1933-1953. 
Es-Salâtü ve's-Selâmü aleyke Yâ Resûlallah,

Es-Salâtü ve's-Selâmü aleyke Yâ Habîballah,

Es-Salâtui ve's-Selâmui aleyke Yâ Nebiyyallah,

Es-Salâtü ve's-Selâmü aleyke Yâ Hayra halkîllâh,

Es-Salâtü ve's-Selâmü aleyke Yâ Seyyide'l-Evvelîne ve'l-Âhirîn, ve'lHamdü li'llâhi rabbi'l-Âlemîn.

Hatip Zâkirî Hasan Efendi'nin (1545?- 1623) Cưma ve bayram günleri okunmak için yaklaşık 380 küsûr yıl önce bestelemiş olduğu salâtı vardır. ${ }^{32}$ Fakat bunu genellikle müezzinler bilmediklerinden, sözleri yukarda geçtiği şekilde ve istedikleri makamdan okumaktadırlar.

bb- Bayram Salatı: Müslümanların yılda iki adet dinî bayramı vardır. Bunlardan birisi 1 şevvâl'de başlayan Ramazan veya Fitre Bayramı, diğeri de 10 zilhicce'de başlayan Kurban Bayramıdır. Bu iki bayram münâsebetiyle, bayramın ilk günü sabah namazından sonra okunan salâttır. Bu salât, Hatip Zâkinî Hasan Efendi tarafından bestelenmiş olup, yukarıda geçtiği üzere Bayram ve Cumâ Salâtı adını almıştır.

$\mathrm{Bu}$ eser, bayram ve Cuma namazlarından önce, müezzin mahfilinde, baştaraftaki "Yâ Mevlâ" sözünü cemaat okur, sonra bir müezzin "Leyse'l-îdü limen lebise'l-cedîd" den bir cümle okur, onun peşinden cemaat "Yâ Mevlâ" ve bir müezzin diğer cümleyi okurlar. "Nasrun mina'llâhi ve fethun karîb"i bir müezzin şifâhen cemâate okur; bundan sonra yine bir müezzin "Ve salli ve sellim alâ es'adi ve eşrafi nûr-i cemii'l-enbiyâi ve'l-mürselîn"i terennüm eder ve bütün müezzinler "Ve'l-hamdü li'llâhi rabbi'l-âlemîn"i okuyarak bitirirler. ${ }^{33}$

Bayram salâtının Arapça sözleri şöyledir:

Leyse'l-îdü limen lebise'l-cedîd, Inneme'l-îdü limen hâfe mine'l-vaîd.

Leyse'l-îdü limen rakibe'l-matâyâ, İnneme'l-îdü limen terake'l-hatâyâ.

Leyse'l-îdü limen basata'l-bisât, İnneme'l-îdü limen tecâveze ale'ssirât.

Leyse'l-îdü limen tezeyyene bi-zînetid-dünya, İnneme'l-îdü limen tezevvede bi-zâdi't-takvâ.

Leyse'l-îdü limen nazara envâe'l-elvân, İnneme'l-îdü limen nazara cemâle'r-rahmân.

\section{Anlamı}

Bayram, yeni elbise giyenlerin değil, Allah'ın azabından korkanlarındır.

32. Öztuna, a.g.e., I/ 103.

33. Ezgi, a.g.e., III/ 66. 
Bayram, binek hayvanlanna süvari olanların değil, hatalan terkedenlerindir.

Bayram, örtui ve yaygılan yayanların değil, sırâtı geçenlerindir.

Bayram, dünya zînetine bürünenlerin değil, Allah korkusunu düstûr edinenlerindir.

Bayram, çeşitli renklere bakanların değil, Allah'ın cemâlini görenlerindir.

Günümüzde bu salât formu unutulmuş ve ne yazık ki bilen de kalmamıştır.

bc- Cenâze Salâtı: Cenâzenin götürülmesi esnasında ve defnedilmesinden sonra okunan salâttır. Üslûbu acıklı, dinî ve zâhidâne bir şekli vardır. Yüzyıllardan beri memleketimizde Zâkirî Hasan Efendi'nin Hüseynî Cenâze Salâtı okunmuş, ancak son 50 yıl içerisinde unutulmaya yüz tutmuş eserlerimizden birisidir.

Cenâze salâtının sözleri şöyle okunmaktaydı: Cenâze yolda götürülürken birisi tarafından "Lâilâhe illallah, vahdehû lâ şerîke leh, velâ nazîra leh, Muhammedün Emînu'llâhi hakkan ve sıdka, Allahumme salli alâ seyyidinâ Muhammedin ve alâ..." bundan sonra cemaat tarafından: "Ve alâ âli Muhammed" okunur.

\section{Anlamı}

"Allah'tan başka tapılacak yoktur, O birdir, ortağı ve benzeri yoktur; Muhammed, hakikaten ve gerçekten Allah'ın emînidir. Allahım, Efendimiz Muhammed'e ve ailesine rahmet eyle".

Cenâzenin defnedilmesinden sonra bir kişi tarafından: "Ve salli ve sellim alâ es'adi ve eşrafi nûri cemîi'l-enbiyâi ve'l-mürselîn"34 ve cemaat tarafından da "Ve'l-hamdü li'llâhi rabbi'l-âlemîn"35 okunur.

bd-Sabah Salâtı: Cuma sabahı veya bayram sabahlarında, ezandan önce minârede güzel sesli karşılıklı iki müezzin tarafından Dilkeş-hâverân makamında okunan sabâ salât, Hatip Zâkin̂ Hasan Efendi'ye ait olup, Dr. Duphi Ezgi tarafından Durak Evferi usûlüyle yazılarak yayımlanmıştır.

Sabah Salâtının sözleri şöyledir:

Es-salâtui ve's-selâmu aleyke Yâ Seyyidenâ Yâ Resûlallah;

Es-salâtui ve's-selâmu aleyke Yâ Seyyidenâ Yâ Habîballah;

34. "Bütün elçilerin ve peygamberlerin nurlarının en şereflisi ve en mutlusuna ( $\mathrm{Hz}$. Muhammed'e) salât ve selâm et" demektir.

35. "Hamd, âlemlerin rabbı olan Allah içindir" demektir. 
Es-salâtü ve's-selâmu aleyke Yâ Seyyidenâ Yâ Nebiyyallah;

Es-salâtü ve's-selâmu aleyke Yâ Seyyidenâ Yâ Hayra halkîllâh; Es-salâtü ve's-selâmu aleyke Yâ Seyyidenâ Yâ Nûra arşi'llâh Allah, Allah, Allah, Mevlâ, Hû.

be- Salat-1 Ümmiyye: Câmilerde ve diğer meclislerde, dinî törenlerde, belirli dinî gün ve gecelerde, Sakal-ı Şen̂f ve Peygamberimize ait eşyanın ziyareti esnasında ve cenâzelerde, mevlîd programlarında okunan salâttır.

Bugün İslâm dünyasının elinde bulunan Segâh makamındaki Salât-1 Ümmiyye, Büyük Türk Bestekarı Buhûrî-zâde Mustafa Itrî tarafından bestelenmiştir ${ }^{36}$ Türk Mûsikîsînin en büyük birkaç eserinden birisidir.

Salat-ı Ümmiyye'nin sözleri şöyledir:

"Allahumme salli alâ Seyyidinâ Muhammedini'n-Nebiyyi'l-Ümmiyyi ve alâ âlihî ve sahbihî ve sellim". ${ }^{37}$ Salât-1 Ümmiyye'nin usûlü tam olarak kestirilemediğinden, Semâi 3/4, Aksak Semâi 10/8, bir Nîm-Evsat ve iki Aksak Semâi Evferi olmak üzere dört ayrı usûlde yazılmıştır.

\section{c) $T e v s ̧ \hat{\imath} h$}

"Süslemek" demektir. Mevlîd ve Mîrâciyenin bölümleri arasında topluca okunan, sözleri $\mathrm{Hz}$. Muhammed'in doğumundan ve O'nun vasıflarından bahseden, bir çeşit besteli Câmi Mûsikîsi formudur. Câmi ve mevlîdlerde okunan na'tlara tevşîh denir.

Tevşîhler çoktur. Ekseriyetle Sofyan, Düyek, Yürük Semâi, Muhammes, Devr-i Kebîr, Çenber, Hafîf, Evsat, Fahte usûlleriyle ölçülmüşlerdir. ${ }^{38}$

Tevşîhlerin sözleri, iki, dört, beş, altı mısradan meydana gelen bir kıta olur. Genellikle büyük mutasavvıflann şiirlerinden seçilmiş ve değişik makamlarda bestelenmiştir.

\section{d) Tesbîh}

"Sübhân'allah" diyerek Cenâb-1 Hakk'ı yüceltmek, O'nu şanına yakışmayacak sıfatlardan uzak tutmaktır. Allah Teâlâ'yı bu şekilde yücelten eserlere tesbîh denilmektedir.

Tesbîh çeşitlerinden bugün elimizde mevcut iki örnek bulunmaktadır. Birisi Ramazan ayında ve diğer mübârek gecelerde, sabaha karşı müezzinler

36. Dr. Suphi Ezgi'ye göre Salât-ı Ümmiyye'nin bestesi de Hatip Zâkiñ Hasan Efendi'ye aittir.

37. Anlamı: "Allahım, okuma-yazma bilmeyen Peygamberimiz Muhammed'e, âilesine ve arkadaşlarına rahmet et" demektir.

38. Ezgi, a.g.e., III/ 76; Öztuna, a.g.e., II, 2. Kısım, s. 318. 
tarafından minârelerde okunan Temcît ve Münâcaat olup, diğeri de Tesbîh merasimine ait olan Mahfel Sürmesidir. ${ }^{39}$ Bir de "Sübhâne" kelimesiyle başlayan ilâhiler vardır ki bunlara da "Tesbîh" denir.

\section{e) Mahfel Sürmesi}

Câmilerde namazdan sonra, bir veya birkaç müezzinin mahfelden, kısım kısım ve nöbetleşerek, geleneksel bestesi ile okudukları beş bölümlü (dua, âyete'l-kürsî, tesbîhler, İlâhî ve dua) Arapça esere mahfel sürmesi denir. İrticâlen ve değişik makamlardan usûlsüz olarak okunan bu eser, hâlen câmilerde, namazlardan sonra, bazı değişikliklerle uygulanmaktadır.

Farz namazlardan sonra müezzin "Allahümme ente's-selâmu ve minke's-selâmu tebârekte yâze'l-celâli ve'l-ikrâm" der. Önceleri biraz daha uzun ve değişik olarak:

"Allhümme ente's-selamu ve minke's-selâm ve ileyke yeûdü's-selâm; fe hayyinâ rabbüna fi's-selâm ve edhilnâ dâre's-selâm; tebârekte Rabbenâ ve teâleyte leke'l-hamdu ze'l-celâli ve'l-ikrâm." şeklinde okunurdu. Sonra âyete'l-kürsî okunurdu. Bu duâlann hepsi müezzinler tarafından birlikte okunurdu.

Bugün tatbik edilen şekli ise: Âyete'l-kürsî'den sonra 33 defa "Sübhânallah", 33 defa "el-Hamdülillâh", 33 defa "Allahu ekber" okunur. Bu tesbihlerin başlangıcını müezzin verir. Cemaat içinden bu tesbîhleri okur. Daha sonra müezzin "lâilâhe illallâhu vahdehû lâ şerîke leh, lehu'l-mülkü ve lehu'l-hamdu ve Huve alâ kulli şey'in kadîr, sübhâne Rabbiye'l-aliyyi'la'le'l-vehhâb" diye okur ve duâ yapilır. Duâdan sonra bir aşr-i şerîf okunur. Buna "mihrâbiye" de denir. Önceleri daha teferruath yapılan tesbîh merâsimi bugünkü şekliyle kısaltılmıştır. Aşir bittikten sonra salât-ü selâm ve arkasından Fâtihâ Sûresi okunur ve eller yüze sürülerek namaz bitirilmiş olur.

Bazı câmilerde farz namazlardan önce üç defa "İhlâs" sûresi okunur ve peşinden "el-Fâtiha" denerek geç kalan cemaat varsa onların namaza yetişmesi sağlanmış ve bu vesîle ile sevâbı artırarak tüm ölmüşlerimizin ruhlarına da bağışlanmış olunur. Tesbîh, günümüzde dahi her câmide aynı okunmayıp, az çok farklı olarak birbirinden ayrılmaktadır. ${ }^{40}$

Mahfel Sürmesi ile cuma günü iç ezanını, Sultan III. Ahmet zamanında, Eyüp Câmiî baş müezzini Şeyh Abdülganî Gülşenî'nin îcad ettiği söylenmektedir. ${ }^{41}$

39. Ezgi, a.g.e., III/ 67.

40. Mehfel Sürmesinin eski okunuş şekli için bkz. Ezgi, a.g.e., III/ 75.

41. Şeyh Abdülganî Gülşenî'nin Mahfel Sưrmesi için bkz. Ezgi, a.g.e., III/ 72. 


\section{f) Temcîd ve Münâcaat}

Temcîd, Arapça'da "mecd" kökünden gelen bir masdar olup, "büyüklemek, ululamak" anlamlarına gelmektedir. Ramazan geceleri ve diğer mübârek gecelerde, genellikle sahurdan sonra, sabah namazından önce bir müezzin ile koro tarafindan okunur. Temcîd'in sözleri, Cenâb-1 Hakk'ı yüceltme ifadeleriyle doludur, onun için dinî mûsikîde bu forma temcîd adı verilmiştir.

Temcîdten sonra genellikle münâcat okunur ve Cenâb-1 Hak'tan dilekte bulunulur. Bu sebeple Temcîd ve Münâcat ikisi beraber, dinî mûsikîde tek bir form gibi zikredilmiştir. ${ }^{42}$

Temcîd'in güftesi kısa, açık ve Arapça'dır. Türkçe şiirlerin bestelenmesiyle yapılan münâcattan ayrı bir şekli vardır. Nağmeleri tekrarlanmak suretiyle "Tevhîd" duygusu telkîn edilir. Bugün Hatîp Zâkirî Hasan Efendi'ye ait Irak makamında bir Temcîd ve Münâcat'ın notası elimizde mevcuttur.

Temcîd'in sözleri şöyledir:

Yâ Hazreti Mevlâ; mevle'l-mevâlî, ente'l-kerîmü'l-bâkî ve ente'rrahîmü Yâ Allah;

Ente'llezî teferradte bi'l-fadli ve'l-kerami ve'l-ulâ Yâ Rahmân;

Ilâhun vâhidun, Rabbün Teâlâ huv'allâhü'l-bedîu'l-hakku'l-ulâ Yâ Mennân;

Teâlâ Zâtuhû lemmâ tecellâ mine'l-gaybi ile'l-ayni fe-cellâ Yâ Mennân;

Sübhâne men tâbe alâ deme ba'de mâ asâ, fectebâhu rabbuhû ve rafea ile's-semâvâti'l-ulâ Yâ Sübhân;

Sübhâne men encâ Nûhan ile's-sefîneti ve eshâbehû, sübhâne men ersele Mûsâ ilâ Fir'avne bi'l-asâ Yâ Deyyân;

Sübhâne men ahsene savte Dâvûde ve rafea Isâ, sübhâne men ittahaze İbrâhîme halîlen ve ıstafâ Yâ Rıdvân;

Sübhâne men tecellâ ve kelleme Mûsâ Yâ Hannân;

Sübhâne men hâteme'l-enbiyâe bi-Muhammedini'l-Mustafa, fidâke ebî ve ümmî keme'l-halîlu İsmâîle fedâ; Allah Yâ Hazreti Mevlâ;

Lâilâhe illa'llah, hak lâilâhe illa'llah, lâilâhe illa'llah;

Evvel Âdem Safiyyu'llah Yâ Hazreti Mevlâ; lâ ilâhe illa'llah, Nûh neciyyu'llah, Yâ Hazreti Mevlâ;

Lâ ilâhe illa'llah Yusûf Sadiku'llah Yâ Hazreti Mevlâ;

Lâilâhe illa'llah, Mûsâ Kelîmu'llah, Yâ Hazreti Mevlâ;

Lâilâhe illa'llah, Îsâ Rûhu'llah, Yâ Hazreti Mevlâ;

42. Ezgi, a.g.e., III/ 72. 
Lâilâhe illa'llah, Muhammedün Rasûli'llâhi hakkan ve sıdkan ve salli ale'n-nebiyyi'l-Mustafâ;

Ahmedüne'l-Hâdî ve aleyhi's-senâ; Kerîmun, Rahîmun Allah, Yâ Mevlâ.

\section{Anlamı}

Efendilerin efendisi olan Hazreti Mevlâ; sen Kerîmsin, Bâkîsin, sen Rahîmsin Yâ Allah;

Sen ki fadl-ü kerem ve ulviyette eşsiz oldun Ey Rahmân;

Tek bir tanndır, yüce Rab'tır, Bedî', Hak, Âlî olan ilâhtır, Yâ Mennan;

Gaybtan göze tecellî ederek zâhir olunca zâtı yücelmiştir, Yâ Mennân;

Adem (A.S.)'ın isyanından sonra onu affeden ve sonra onu seçerek göklere çıkaran Cenâb-1 Hakk'ı tesbîh ederim, Yâ Sübhân;

Hz. Nuh ile ashâbını gemiye alıp kurtaran Allah'ı tesbîh ederim; Firavun'a Hz. Mûsa'yı âsâ ile gönderen Cenâb-ı Hakk'ı tesbîh ederim, Yâ Deyyân;

Hz. Dâvud'un sesini güzel halkeden ve $\mathrm{Hz}$. Îấyı göğe yükselten Tanri'yı tesbîh ederim ve Hz. İbrahim'i dost edinen Ilâh'ı tesbîh ederim, Yâ Ridvan;

Mûsâ'ya görünüp, onunla mükâleme eden Tanrı'yı tesbîh ederim, Yâ Hannân;

Peygamberleri Muhammed Mustafâ ile nihayetlendiren Allah'ı tesbîh ederim, nasıl ki, Íbrahim Halîlu'llah, İsmâil'i fedâ etmişse, benim de anam babam sana fedâ olsun, Yâ Hazreti Mevlâ;

Allah'tan başka ilâh yoktur, gerçekten Allah'tan başka tapılacak yoktur, Allah'tan başka tapılacak yoktur, Allah'tan başka ilâh yoktur;

Evvel Âdem Safiyyu'llah; Nûh Neciyy'ullah; Yusuf Sadiku'llah; Mûsâ Kelîmu'llah; Îsâ Ruhu'llah; Yâ Hazreti Mevlâ, Allah'tan başka tapılacak yoktur, Muhammed hakikaten ve gerçekten Allah'in elçisidir.

Bize doğru yolu gösteren güzîde Peygamberimize salâtü selâm, ve Allah'ın senâsı onun üzerine olsun, Yâ Hazreti Mevlâ, Kerîmdir, Rahîmdir, ${ }^{43}$ Allah, Yâ Mevlâ.

Münâcat, "yalvarma, dilekte bulunma" demektir. Temcîd'ten sonra Cenâb-1 Hakk'a münâcatta bulunulur. Münâcat'ın sözleri şöyle olur:

Yâ Hâteme'r-risâleti Yâ Eşrafe'l-Verâ; aceben li'l-muhibbi keyfe yenâm;

Âşiku'llâhi ve yenâm; ed'ûke bi't-tadarrui Yâ Dâime'l-bekâ;

Aslih lenâ bi-fadlike Yâ Vâsi'l-atâ; ilâhî ben kimim idem münâcat;

43. Ezgi, a.g.e., III/ 71 . 
Kapunda eyleyim arz-1 hâcât ve Yâ Dânende-i sırr-1 hafiyyât; Yezâl;

Ne hâcet Hazretine arz-1 hâcât; Ey kerîmu lem yezel vey Pâdişâhı lâ

Saltanât-1 küllî senindir, hiç sana irmez zevâl; Salli alâ Seyyidinâ Mustafâ, Ahmedûne'l-Hâdî aleyhi's-senâ.44

Temcîd ve münâcat'ın okunmasını, Dr. Suphi Ezgi, "Nazarî ve Amelî Türk Mûsikîsi" adlı eserinde şöyle anlatmaktadır: [... evvelâ temcîd'in birinci cümlesinin iki devrelik lâhnini bir müezzin okur, onu takiben üçüncü devre olan mülâzimeyi müezzinler cumhûren terennüm ederler; bu suretle eser münferiden ve cumhûren nihayetine kadar okunur; Hz. Âdem'den Peygamberimize dek isimleri yazılı peygamberlerin isimleri $\mathrm{Hz}$. Âdem'den evvelki üç defa "lâilâhe illa'llah" ve Âdem Safiyyu'llah'ın bestesiyle okunur. İstenirsse onlar hazfolunarak, Peygamber Efendimiz'in cümlesi terennüm olunur; lâhin bittikten sonra minâreden halka hitâp edilir vẹ aynı müezzin "Nasrun minallâhi ve fethun karîb ve beşşiri'l-mü'minîne Yâ Muhammed" ve sonra "bi-ismike" der; cumhûr "Yâ Allah hu" diye bitirirler...].45

\section{g) $N a^{\prime} t$}

Arapça'da "vasıflandırmak, sıfatlarını söylemek, nitelemek" anlamlarına gelmektedir. Peygamberimizin vasıflarını Türkçe, Arap̧̧a, Farsça şiirlerle bildiren ve çeşitli makamlarda bestelenen dinî eserler olup, Türk şiir ve mûsikîsinde bir formdur. Konusu itibariyle bu adı almıştır. Şayet bir kasîde Hz. Peygamber'i medhederse "Na't" adını alır.

Na't, hem Câmi Mûsikîsinde ve hem de Tekke Mûsikîsinde olan ortak bir formdur. Na'tlar, câmilerde, cuma ve bayram namazlarından önce Kur'ân-1 Kerîm okunduktan sonra okunur. Tekkelerde, zikir fâsilalarında Kelime-i Tevhîd ile Ism-i Celâl arasında bir hâfız tarafından yalnız olarak okunurdu. 46

Divân edebiyatında kasîde türünde yazılmış bir çok na't vardır. Na'tlar, Ilâhî usûlleriyle ölçülürler, az kullanılan bir formdur. Na'tların İlâhî gibi usûlle bestelenmiş şekilleri vardır ki, bunlar İlâhîden pek farklı değildir.

Mevlevî âyininde okunan Na't-1 Mevlâna vardır ki, Güftesi Mevlâna Celâleddin Rûmî'ye ait olup, usûlsüz olarak bestelenmiştir. En tanınmı̧ Nâ't-1 Mevlâna "Yâ Habîballah Resûl-i hâlik-1 yektâ tûyi" diye başlayan na'tıdır ki, Itrî tarafından Rast makamında bestelenmiştir.47

44. Ezgi, a.g.e, III/ 67.

45. Ezgi, a.g.e., III/ 72.

46. Öztuna, a.g.e., II, 2. Kısım, s. 65; Ezgi, a.g.e., III/ 54.

47. Karadeniz, a.g.e., s. 705. 


\section{h) Tekbîr}

"Yüceltmek" anlamındadır. Cenâb-ı Hakk'ı yüceltmek, büyüklüğünü ifâde etmektir.

Tekbîr, özellikle bayram günleri namazdan evvel ve hutbe sözleri arasında okunur. Sözlerinin tamamı şöyledir:

Allahu Ekber Allahu Ekber,

Lâilâhe illallahu Vallahu Ekber,

Allahu Ekber ve lillâhi'l-hamd.

\section{Anlamı}

"Allah en büyüktür, Allah en büyüktür,

Allah'tan başka ilâh yoktur, yemin ederim ki Allah en büyüktür.

Allah en büyüktür ve hamd Allah'a mahsustur".

Tekbîr, harpte savaşa başlamadan okunur. Ayrıca dinî merasimlerde, toplantılarda, mevlîdlerde, Sakal-ı Şerîf ziyaretlerinde okunmaktadır. Önceleri Cuma günleri de okunduğu kaynaklarda geçmekteyse de zamanımızda böyle bir uygulama yoktur.

Tekbîr, segâh makamında usûlsüz olarak bestelenmiştir. Bugün, İslâm dünyasında okunan tekbîr'in bestecisinin Hatip Zâkin̂ Hasan Efendi olduğunu söyleyenler varsa da, Itrî tarafından bestelendiği görüşü çok yaygın ve hâkimdir. ${ }^{48}$

\section{i) Tardiyye}

"Allah razı olsun" demektir. Cuma ve bayram hutbelerinde, hatîbin, minberde önce Peygamberimize ve ailesine salât ve selâm okuduktan sonra Dört Halîfe'yi ve arkasından $\mathrm{Hz}$. Hasan ile Hüseyin'i anması ve bu sırada mahfeldè bulunan müezzinlerden birisinin "Radıyallahü anh" (Allah ondan razı olsun) diye nidâ etmesidir.

Bugün tatbik edilmeyen bu dinî mûsikî formu, bazı yerlerde klâsik hutbe okuyan hatipler tarafindan Dört Halîfe ve arkasından Peygamberimizin iki sevgili torunu zikredilip hepsine birden hatip tarafından "Rıdvânu'llâhi Teâlâ aleyhim ecmaîn" (Allah onlann hepsinden razı olsun) şeklinde okunmaktadır.

Tardiyye her hatip tarafından irticâlî olarak okunmaktadır.

\section{k) Mîrâciye}

Lügatte, "merdiven, çıkacak yer, göğe çıkma" anlamlarına gelen mîrac kelimesi, özellikle Hz. Peygamber'in göğe çıkarılması hadisesi için kullanılmıştır.

48. Ezgi'nin adı geçen eserinin III. Cilt, 66. sayfasında, Irak makamında, Hatip Zâkini Hasan Efendi'ye ait Bayram tekbîrinin notası bulunmaktadır. 
İnsanlık tarihinin olağanüstü hadislerinden biri olan mîrac gecesine ait müstesna mucizenin harikulade safhalarını tasvir eden manzûmelere mîraciye adı verilmektedir.

Mîraciyeler içinde en meşhuru XVIII. Yüzyllın ilk yarısında yetişen Kutbi Nâyi unvanıyla tanınmış Osman Dede (1652-1730) 'ye ait olanıdır.

Mîraciye altı ayrı makamdan meydana gelmiştir. Bunlar; Segâh, Müstear, Dügâh, Nevâ, Sabâ ve Hüseynî makamlannda altı hâne ile, Nişabur makamında münâcat hânesi ve her hâne başında yer alan beş adet tevşîhten meydana gelmiştir.

Mîraciyenin hangi günlerde okunacağına dair kesin bir kaide olmamakla birlikte, teamüle göre Mîrac Kandili ve onu takip eden gece okunması tercih edilmektedir. Önceleri Mevlevî Tekkelerinde, daha sonra diğer tekke ve evlerde okunması âdet olmuştur. Eserin icrâsı şöyledir:

Önce İsrâ ve Necm sûresinden bir aşır okunur, daha sonra Mîraciye metni iki mîrachan tarafından okunur. Her mısranın okunmasından sonra zâkirler korosu "sallu aleyh", "İkbel yâ Mucîb, ikbel yâ Mufîd..." sözleri aynı makamda ve hep bir ağızdan tekrar ederler. Mîraciye bittikten sonra Kur'ân-1 Kerîm'den Necm sûresinin ilk 18 âyeti veya Bakara sûresinin sonları bir hafız tarafından okunur. Merasim, duahanın duasıyla sona erer. Bu tören birkaç saat sürmektedir.

$\mathrm{Bu}$ eser, makam bakımından da zengin olması hasebiyle mûsikîşinaslara, bestekarlık ilminin her şûbesini de öğretecek kadar önemlidir. Şâiri, Şeyh Nasûhî olan bu Mîrâciye'nin notası yaklaşık olarak 40 sayfay bulmaktadır. ${ }^{49}$

\section{B- TEKKE (TASAVVUF) MÛSIKÎSI}

Türklerde Tekke Mûsikîsi, ilk Türk Tarîkati olan Yesevilikle başlamıştır. Bu tarîkat, büyük Türk Mutasavvıfı Hoca Ahmet Yesevî (ö. 562/ 1166-7) tarafından Oğuz Han'ın başşehir olarak kullandığı "Yesi" şehrinde yaklaşık 800 yıl kadar önce kurulmuştu. Ahmet Yesevî, Yesevî Tarîkatı'nın ve Tasavvuf Edebiyatının kurucularındandır. "Hikmet" adını verdiği şiirlerinden kolay İlâhîler tanzim etmiş ve müritlerine bunları tekkesinde icrâ ettirmiştir. Yesevî'nin dervişleri, bu İlâhîleri derin bir sûfilik anlayışı içinde zâhidâne bir tavırla okuyarak zikir yapmışlardır.

Yesevî'nin ölümünden sonra, onun dervişleri Türk ülkelerine ve Anadolu'ya yayılarak, gittikleri yerlerde kendi tekkelerini kurmuşlar ve öğrendiklerini buralarda yaymışlardır.

49. Eserin notası ve daha geniş bilgi için bkz. Ezgi, a.g.e., III/ 102- 143. 
Bu sıralarda Anadolu Selçuklulan zamanında Mevlâna Celâleddin-i Rûmî ikinci Türk tarîkatı olan Mevlevîliği kurmuştu. Böylece tekke mûsikîsinde yeni bir ilerleme başlamıştı. Mevlevîlikte âyinlere, raksa ve mûsikî âletlerine karşı sempati ve ruhsatın olması sonucu, önceleri yalnız sesle icrâ edilen Tekke Mûsikîsi, bu defa sazların da iştirakiyle icrâ edilmeye başlanmış ve dolayısıyla def' in dışındaki bu aletlerin çalınmasına da izin verilmiş oluyordu.

Konya Selçuklu Devleti'nin yıkılmasından sonra, Osmanlı döneminde Anadolu'da tekkeler gün geçtikçe artmış, zikir esnasında icrâ edilen Dinî Mûsikî çeşitli isimlerle dallara ayrılmıştı. Tekkeler çok büyük bestekârların yetişmesinde önemli rol oynamış, Türk Mûsikîsinin şah eserleri, buralardan yetişen bestekârlar tarafından bestelenmiş̧ir. Tekkeler sadece musikîşinas yetiştirmekle kalmamış, çok değerli edebiyatçı, şâir ve yazarlar hep bu ocaktan çıkmışlardır. Özellikle Mevlevîler mûsikîmize çok hizmet etmişler, araştırılacak olursa, en büyük bestekâr ve virtüözlerin bu tarîkatın ileri gelenlerinden olduğu görülür.

\section{a) Tekke (Tasavvuf) Mûsikîsinin Bölümleri}

\section{I-Mevlevî Mûsikîsi}

Mevlevî tarîkatına mahsus mûsikînin adıdır. Mevlevî tarîkatı mûsikîye çok önem vermiştir. Mevlevî mûsikîsinin en büyük formu "Âyin-i şerîf"tir. Âyin-i Şen̂flerin icrâsında saz ve söz mûsikîsi oluşmuştur. Bir de bu mûsikî ile yapılan raks vardır ki buna da "semâ" adı verilmektedir. 50

Hz. Mevlâna'yı sadece, tarîkat kuran bir tekke şeyhi veya bir pîr olarak görmemek gerekir. O, İlâhî aşkın, insan sevgisinin, mûsikînin ve raksın cisimleşmiş şeklidir, sembolüdür. Mevlâna, Mesnevî'sinde ve Dîvân-t Kebîr' inde hep mûsikîyi, aşkı ve semâyı övmüş, methetmiştir.

Mevlevî Âyinleri, her birine "selâm" denilen dört bölümden oluşmaktadır. Âyine başlamadan önce bir baş taksim yapılır. Sonra Mevlâna'ya ait Itr̂́'nin bestelediği na'tı okunur, ondan sonra âyinin makamında bir peşrev çalınır ve âyine girilir.

Birinci selâm, Düyek veya Devr-i Revân; ikinci ve dördüncü selâmlar Ağır Evfer; üçüncü selâm Devr-i Kebîr, Frenkçin, Ağır Düyek, Çenber, Evsat ve Semâî gibi usûllerden birisiyle ölçülür. ${ }^{51}$ Her selâm başında, dönenler durarak vücutlarını hafifçe öne eğmek sûretiyle selâm durumunu yerine getirmiş olurlar. Birinci selâmın bittiği, ritmin değişmesiyle belli

50. Öztuna, a.g.e., II, 2. Kısım, s. 29.

51. Özkan, a.g.e., s. 82. 
olduğundan, mutribân (sâzende ve hânendeler) ikinci selâmı Evfer usûlü ile icrâ etmeye başladıklanı vakit, bütün semâzenler dururlar. Posttaki şeyh ụ̧̈ adım ilerleyerek selâm verir, semâzenler de aynı selâma uyarlar. Şeyh tekrar geriye çekilerek bir daha selâm verir. Semâzenler de bu selâma iştirak ederler ve semâzenler şeyhin önüne gelir; yalnız selâm vererek tekrar dönmeye başlarlar.

Âyinin üçüncü bölümünde yine usûlün değişmesi ile, ikinci selâmda olduğu gibi yapılır. Bu bölüm, Devr-i Kebîr ve diğer usûller ile icrâ edilir. Neylerle terennüm adı verilen sâz eseri çalındıktan sonra, Ahmet Eflâkî Dede'nin tertip ettiği ve bütün âyin bestelerinde bulunan Yürük Semâî usûlünde bestelenmiş "Ey ki hezâr âferin bu nice sultân olur" kıtası okunur. Âyinin en uzun kısmını üçüncü selâm teşkil eder. Sonra dördüncü selâma geçilir.

Dördüncü selâma şeyh de katılır. Selâmın sonunda, âyinin son bulduğu makamda ve Düyek usûlünde dört bölümlü son peşrev çalınır. Bundan sonra neyzenbaşı veya onun emriyle neyzenlerden biri tarafından son taksim yapılır. Sonra Yürük Semâî usûlünde son peşrev icrâ edilir. Böylece şeyh post önüne gelmiş olur. Mutribde bulunan hafızlardan birisi tarafından Kur'ân-1 Kerîm'den kısa bir sûre okunduktan sonra, ayakta dönenler bu defa kenarlara çekilip namazdaki gibi otururlar. Semâzenbaş1 ayağa kalkıp postun önüne yaklaşarak bir dua okur, şeyh de "Fâtiha" dedikten sonra hep beraber ayağa kalkarlar ve şeyh tarafından bir gülbank ${ }^{52}$ okunur. Gülbank, hep birlikte "hu" sözü ile son bulur. Şeyh Efendi, semâhâneden çıkarken semâzenleri ve halkı "Es-selâmu aleyküm" diye selâmlar. Semâzenbaşı buna "Ve aleyküm selâm ve rahmetullâhi ve berakâtühü" diyerek karşılık verir. Ağır adımlarla yürüyen şeyh, mutrib hizasına gelince neyzenleri ve kudûmzenleri aynı şekilde selâmlar. Buna da mutribden neyzenbaşı karşılık verir. Böylece semâ âyini bitmiş olur. ${ }^{53}$

\section{2- Bektâşî Mûsikîsi}

Tekke Mûsikîsinin bir çeşidi sayılan Bektâşî Musikîsi, Bektâşî dergâhlarında icrâ edilen mûsikîdir. Mevlevî Mûsikîsinden sonra en zengin olan bir tarîkat mûsikîsidir. Bu mûsikînin en önemli özelliği, halk mûsikîsi ile yakın olmasıdır.

52. Gülbank, dua demektir. Mevlevî Gülbankı denilince, Âyin-i Şerîf sonunda şeyhin yaptığı dua anlaşılır. Bektâşî Gülbankı, Bektâşî savtına verilen ad. Yeniçeri Gülbankı, Esnaf Gülbankları, Tulumbacıların yangına giderken söyledikleri gülbank ve Mehter Gülbankı gibi çeşitleri vardır.

53. Öztuna, a.g.e., I/ 87. 
Bektâşî Mûsikîsi'nin önemli mahsûlü, bu tarîkatın İlâhîsi sayılan ve tasavvufî Türk Edebiyatı'ndan alınmış bir kısım şiirlerden oluşan "nefes" lerdir. Bunlar, Bektaşîlerin inanç ve görüşlerini ortaya koyan, dinî olmaktan çok $\mathrm{Hz}$. Ali'yi öven, onun meziyetlerini dile getiren, vahdet-i vücutçu geleneğe bağlı besteli eserlerdir. Bestesiz olanlarına "nutuk" adı verilmektedir.

Âyin-i Şerîflerin yalnız Mevlevî Mukâbelelerinde kullanılması gibi, nefesler de sadece Bektâşî Âyinlerinde icrâ edilir. İlâhîler, bütün tasavvuf şûbelerinde kullanılmaktadır.

Nefesler, Ilâhîlerden ayrı olarak daha çok şarkı ve türkülere benzerler. İlâhîler ne kadar mutasavvifâne nağmelerle doluysa, nefesler de o derece zâhidâne bir üslûpla bestelenmişlerdir.

Bektâşî Âyinlerinin iki bölümden meydan geldiği söylenmektedir:

Birinci bölümde, önce Kur'ân-1 Kerîm okunur, Peygamberimize salât ve selâm getirilir. Daha sonra $\mathrm{Hz}$. Ali ve evlâdı, bütün Ehl-i Beytin adları saygı ile anılır. Semâhânenin çeşitli yerlerine konulmuş şamdanlar, büyük merâsimle birer birer yakılır. Burada çok rûhânî bir âlem yaşandığ 1 söylenmektedir.

İkinci bölümde, dinî ve rûhânî merâsime ait olan semâhaneden çıkılarak salona geçilir ve burada tam anlamıyla salon hayatı ve onun gereği yeme içme âlemi başlar. Nefesler, bu âlem esnasında hazırda olan saz şâirleri tarafından çalınır. Bu sırada bütün dervişlerin, nefeslerini ciddî bir aşk ve şevk içerisinde dinledikleri ve bazılarının cûşa gelip ayă̆a kalkarak özel bir şekilde raksettikleri de anlatılanlar arasındadır.

\section{3- Kâdirî, Celvetî ve Gülşenî Mûsikîsi}

Kâdinî, Celvetî ve Gülşenî tekkelerinde kullanılan mûsikî çeşidine "savt" denilmektedir. Bu tarîkatlarda, geleneksel nağmelerle veya içten geldiği gibi okunan, Allah'ın birliği konusunu işleyen ve bu duyguları kuvvetlendiren mûsikîdir. Muhtevâsı itibariyle câmi mûsikîsindeki tesbîh'e benzetilmektedir. Tekkelerde zikir esnasında okunmakta ve kısa birkaç cümleden oluşmaktadır.

\section{b) Tekke (Tasavvuf) Mûsikîsi Formları}

\section{ba-Mevlevî Âyini}

Mevlevî Âyini, Mevlevîler tarafından namazın dışında yapılan ve ibadet kabul edilen bir iştir ki, bu işi de mûsikî eşliğinde dönerek yaparlar. Semâ' sırasında çalınan ve söylenen bir müzik vardır. Bu müzik de, sözleri $\mathrm{Hz}$. 
Mevlâna'ya veya oğlu Sultan Veled'e ait olup, büyük mûsikîşinaslar tarafından bestelenmiş eserlerdir.

Bugüne kadar bir çok bestekâr tarafından 130 âyin bestelenmiştir. Tespit edilemeyen âyinler de vardır..$^{54}$

\section{bb-Durak}

Tasavvuf mûsikîsinde bir çeşit llâhîdir. Allah'ı yücelten kasîde tarzında yazılmış şiirlerin Durak Evferi usûlüyle ölçülmesinden meydana gelmiş bir çeşit dinî mûsikîdir. Bu özellikleriyle İlâhîden ayrılır.

Duraklar, oturarak veya ayakta zikir yapan tarîkatların âyinlerinde birinci kısmı teşkil eden Kelime-i Tevhîd'den sonra İsm-i Celâl'e geçilmeden önce verilen fâsılada bir veya iki zâkir tarafından okunan, muhtelif makamlardan serbest vezinde bestelenmiş mutasavvifâne güftelerdir. Kelime-i Tevhîd bitince durulduğundan bu isim verilmiştir. Tasavvuf mûsikîsinin beste yönüyle en güç olan kısımlarındandır.

Duraklar, Ilâhîlerden daha ağır, derin ve îtinalı eserlerdir. Tamamen tasavvufî duygu ve düşüncelerle doludur.

\section{bc-Şŭhâl}

Şuğûl, Arapça'da "meşgûliyet, iş, hizmet" gibi anlamlara gelmektedir. Terim olarak ise, Türkler tarafından bestelenmiş, sözleri Arapça olan Ilâhîlere verilen addır.

Şuğullerin sayısı İlâhîlere nazaran çok azdır. Arapça güfteli İlâhîlere ilk olarak şuğul ismini kimin verdiği bilinmemektedir.

Şuğullerin genellikle tekkelerde zikir esnasında okunduğu söylenmektedir. Şuğullerde Düyek ve Sofyan usûlleri çok kullanılmıştır. ${ }^{55}$

Türkler, Farsça güfteleri bestelemeye XV. Yüzyıldan itibaren başlamışlar, XIX. Yüzyıla kadar devam etmişlerdir. Zekâi Dede'nin 36 şuğûl bestelediği söylenmektedir.$^{56}$

\section{bd-İsm-i Celâl}

"Allah" lâfzına denir. Tasavvuf Mûsikîsinde Kelime-i Tevhîd'den sonra her tanikatın kendine özgü üslûbu ile oturarak veya ayakta "Allah Allah" diye zikretmeleri hakkında kullanılan bir tabirdir. Mevlevîlerin İsm-i Celâl ile zikretmeleri Dinî Mûsikîye girmediğinden burada bahis konusu olan Ism-i Celâl, makam ve mûsikî eşliğinde okunan İsm-i Celâl'dir.

54. Öztuna, a.g.e., $\mathrm{I} / 87$.

55. Karadeniz, a.g.e., s. 167

56. Öztuna, a.g.e., II, 2. Kısım, s. 292. 
Diğer tarîkatlarda, Ism-i Celâl zikrinde kullanılan makam ve tarz ne ise, dervişler bu üslûpta zikir yaparlar. Bu esnada zâkirler de aynı makamda ve tempoya uygun olarak Illâhîler okurlar ve zikri coştururlar.

\section{be-Savt}

Arapça "ses" anlamına gelen bu kelimenin Tasavvuf Mûsikîsindeki yeri ve anlamı çok değişiktir. Kâdirîlerin, Celvetîlerin ve Gülşenîlerin "Usûl İlâhîsi" diye isimlendirdikleri savtlar başka başka olup, her birinin zikir husûsiyetine göre zâkirbaşıların iktidarına bırakılmışıır.

"Çamaşır Savtı", "Tapu Savtı", "Gülşenî Savtı" gibi isimler taşıyan birkaç Illâhînin notasının varlığından bahsedilse de, bu isimlerin nereden geldiğini ve bunların ne demek olduğunu açıklayan bir eser yoktur. Ancak M. Ekrem Karadeniz, "Türk Mûsikîsinin Nazariye ve Esasları" adlı kitabında: "...llâhîlere mahsus güftelerin aynı makam ve usûlle, ancak birbirine benzemeyen çeşitli nağmelerle bestelenmiş başka başka şekillerine savt denir..." 57 demektedir.

\section{bf-Mersiye}

Lügatte, ölen birinin meziyetlerini sayarak acımak anlamına gelen mersiye, teessürü ve hisleri tahrik edecek tasvirler yapar. Mersiye Arap Edebiyatı'nda çok gelişmiş bir şiir türüdür.

Mersiyenin konusu din büyükleri olabilir. Yalnız, Peygamberimiz için yazılmış olanlanına mersiye denilmez. Özellikle Kerbelâ şehitleri ve Hz. Hüseyn hakkında zengin bir edebiyat oluşturacak şekilde mersiyeler söylenmiştir. Iran'da Hz. Hüseyin' in şehit edilmesini konu alan klâsik ve halkın ürünü pek çok mersiye vardır ki, Şî̀ler 10 Muharrem'de bunlan merâsimle okurlar.

Aslında Hz. Hüseyin'i Sünnîler de çok severler, Şiîler bu konuyu ifrata vardırarak işlerken, Sünnîler tarafından ise, bu olay tarihî ve dünyevî bir fâcia olarak değerlendirilir. Ilâhîler arasında bilhassa $\mathrm{Hz}$. Hüseyin için bir çok mersiye vardır. .8

\section{bg-Nefes}

Bektâşî şâirleri tarafından yazılmış ve Bektâşî tekkelerinde okunmak için çeşitli makamlarda ve usûllerde bestelenmiş manzûm Ilâhîlere verilen addır. Hece vezni, açık sâde ve samimi bir dille yazılmış şiirlerden seçilir. Üslûbu, Ilâhîlere nazaran daha basittir. Halk mûsikîsine yakındır.

57. Karadeniz, a.g.e., s. 167

58. Öztuna, a.g.e., ll/ 25-26. 
Nefeslerin Ilâhîlerden farkı, içeriğinde, Peygamberimizle birlikte $\mathrm{Hz}$. Ali'nin methiyesine yer verilmesidir. Yunus'un pek çok şiirleri İlâhî-nefes tarzındadır. Bazı nefesler Osmanlı düzenine karşı Safevî düzenini savunur, Halîfe'ye karşı Imâm'ın otoritesini destekleyici nefesler vardır. ${ }^{59}$

Dinî Mûsikî formları içerisinde zikredilen formlar bunlardan ibarettir. Din görevlilerinin ve din görevliliğine aday olanların bu formlardan haberi olması bir fantezi değildir. Hemen hemen her gün çeşitli vesilelerle, değişik mekânlarda karşılaştığımız bu formlara bir din görevlisinin ilgisiz veya duyarsız kalması düşünülemez. Çünkü bu saydı̆̆ımız formlar, gerek inanç ve gerekse kültür açısından Müslüman Türk milletini yansıtmaktadır.

\section{Sonuç}

Yüzyıllar boyu hâfız, imam ve müezzinlerimiz tarafindan uygulanan Dinî Mûsikî formlanının büyük bir kısmı artık kullanılmamaktadır ve bir kısmı da notalarda kalmıştır. Asırlar boyu gönülleri titreten, câmileri ve diğer ibadethaneleri inleten eşsiz nağmeler unutulmaya yüz tutmuş, mûsikî sanatından yoksun olan din görevlilerimiz de, artık ibadete gelen cemaate, güzel nağmelerle okuyarak şevk veremez hale gelmişlerdir. Okuduğu ezanla kalpleri gaflet uykusundan uyandıran, kıraat ettiği Kur'ân ile gözleri yaşartan, mihraptaki tekbirleriyle ruhlara mânevî huzur serpen, kısaca, sanatkâr bir kafaya ve ruha sahip olan imam ve müezzinlerimizin isimleri artık tarihte kalmış, bunun yerine, estetikten ve sanatçı ruhundan gittikçe uzaklaşan ve salt memuriyet anlayışıyla görev yapan din görevliliği anlayışı toplumumuzda yerini almıştır.

Din olgusu ruhla alâkalı bir olaydır. Bu görevi icrâ edenlerin, ruhları etkisi altına alan müzik sanatından mahrum olması düşünülemez. Bu estetik anlayışa ve sanatçı ruha sahip olmayan kişilerin, imam ve müezzinlik gibi hassas bir mesleği gerektiği gibi icrâ etmesi mümkün değildir. Esasen bu görevler çok nazik görevlerdir. Sanatçı ruhuna sahip olmayan bazı din görevlilerinin, cemaatle iletişimi de zayıftır. Böyle insanlar, kavgacı ve geçimsiz bir mizaca sahip olurlar. Bu tip bir mizaca sahip olan kişi de bu mesleği icrâ edemez. Okuyuşta güzelliği aramayan, ahenkli bir sese sahip olmayan bir din görevlisinin, insanlara karşı davranışlarında zerâfeti ve letafeti gözetmesi mümkün değildir. İmam Gazalî'nin ifadesiyle böyle kişilerin mizacı fâsittir, tedâvisi de mümkün değildir. Dolayısıyla, kendisi hasta olanın, başkalanını tedâvi etmesi de düşünülemez.

Ayrica Diyanet personeli içerisinde yer alan Kur'ân kursu öğreticilerinin de bir mûsikî eğitiminden geçirilmelerinde yarar vardır.

59. Karadeniz, a.g.e., s. 167; Öztuna, a.g.e., II/ 69 
Kur'ân Kurslarındaki öğrencilerin çeşitli yaş ve kültür düzeyine sahip olan halkımızdan oluştuğu göz önünde bulundurulursa, öğreticilerin, Kur'ân öğretirken güzel seslerini kullanmalan, uygun saatlerde bazı dinî formları makamlı olarak terennüm etmeleri, onları mesleklerinde daha câzip hale getirecektir. Zaman zaman öğrencilere bazı İlâhî ve tevşîh gibi dinî mûsikî formlarını öğrettikleri de göz önünde tutulursa, bu görevlilerin de mûsikî hakkında bilgi sahibi olmaları gerekir. Hatta ney ve bendir gibi bazı enstrümanlan kullanarak, öğrencilerin ders öğrenmede şevklerini artırıc1 çalışmalarda bulunabilirler. Bu bakımdan Kur'ân kursu öğreticilerinin de hizmetiçi mûsikî kurslarına katılmaları sağlanmalıdır. Böylece, Kur'ân kurslarındaki monoton eğitim havası, mûsikî faaliyetleriyle daha canlı ve dinamik hale getirilebilir.

Kısaca, biz bu çalışmamızla, din görevlilerinin veya din görevlisi adaylarının, mûsikî açısından tarihteki yerini çok daha güçlü bir şekilde almalanın istiyoruz. Bunun için yapılması gereken şeyler ortadadır. Bu çalışmaların fazla bir maddî külfet getireceğini de zannetmiyoruz. Bu alanın uzmanlarıyla irtibat kurmakla, mevcut elemanlan bu yöne teşvik etmek, biraz heyecan ve biraz da bilgi vermekle bu önemli görevin yerine getirilebileceğine inanıyoruz. Yeni nesli de bu aşk ve heyecanla doldurmalı, halkımıza da, her fırsatta sanat mesajı verilerek, dinleme adabı öğretilmelidir. Ayrıca bu sanatı bilenler tarafından, yukarıda zikredilen hususlar kademeli olarak öğretilmelidir. Zamanla müzik öğretimindeki yeni teknikler uygulanmalı, çağdaş araç ve gereçler kullanılmalıdır.

\section{KAYNAKLAR}

AHMED b. Hanbel, el-Müsned, I-VI, el-Matbaatü’l-Meymeniyye, Misır, 1313.

BUHÂRÍ, Ebû Abdillâh b. İsmail, Sahîhu'l-Buhârî, I-IV (8 củz), İstanbul, 197

EBU DÂVUD, Süleyman b. Eş'as es-Sicistânî, Sünen-i Ebî Dâvud, I-IV, Dâru İhyâi't Türâsi'l-Arabî, Beyrut, Tarihsiz.

MALIK b. Enes, Ebû Abdillâh, el-Muvatta', Dâru İhyâi'l-Kütübi'l-Arabiyye, Beyrut, Tarihsiz.

EZGI, Dr. Suphi, Amelî ve Nazarî Türk Mûsikîsi, III/ 63, İstanbul Konservatuarı Yayını, İstanbul, 1933-1953.

İBN MÂCE, Ebû Abdillâh Muhammed b. Yezîd el-Kazvînî, Sünen-i lbn Mâce, I-II, M.F.A. Bâki neşri, Beyrut, 1975.

IZ’AT, Aytuğ, Türk Gençliğinin Müzik Eğitimi, 27-28 Nisan 1985 Türk Kadınları Kültür Derneğinin "Türk Gençliğinin Müzik Egritimi" konulu Sempozyumda Açış Konuşması, Kadıoglu Matbaası, Ankara, 1985.

ISLÂM ANSIKLOPEDISI, I-XIII, MEB, Istanbul, 1964- 1986.

KARAÇAM, İsmâil, Kur'ân-ı Kerîm'in Fazîletleri ve Okunma Kaideleri, İrfan Matbaası, Istanbul, 1976.

KARADENIZ, M. Ekrem, Türk Mûsikisi'nin Nazariye ve Esasları. Türkiye İs Bankası Kültür Yay., No:238, Ankara, Tarihsiz. 
MÜSLIM, Ebu'l-Hüseyn Müslim b. El-Haccâc el-Kuşeyri, Sahih-i Müslim, I-V, Bcyrut, Tarihsiz.

LÂDIKî̉, Muhammed b. Abdilhamid el-Lâdikî (888/1483'te hayatta), er-Risâletu'l-Fethiyye, Şerh ve Tahkîk: Hâşim Muhammed er-Receb, 1. bsk. Kuveyt, 1986.

MALIK b. Enes, Ebû Abdillâh, el-Muvatta', I-II, Dâru İhyâi'l-Kütübi'l-Arabiyye, Beyrut, Tarihsiz.

NESÂÎ, Ebû Abdi'r-Rahman Ahmed b. Şuayb b. Ali el-Horasânî, Sünenï'n-Nesâî, I-IV (8 cuiz), Beyrut, Tarihsiz.

ÖZKAN, İsmail Hakkı, Türk Mûsikîsi Nazariyan ve Usûlleri Kudüm Velveleleri, Ötüken Neşriyat, 2. bsk., Istanbul, 1987.

ÖZTUNA, Yılmaz, Türk Musikisi Ansiklopedisi, I-II, M.E.Basımevi, İstanbul, 1974.

SUYOTî, Celâlu'd-Dîn Abdu'r-Rahmân, el-Câmiu's-Sağî̀ fî ehâdîsi'l-beşîri'n-nezîr, I-II, Meymeniyye Matb., Misir, 1306.

TÍrMIZî, Ebû İsa, Muhammed b. İsa b. Sevre, Sünenï't-Tirmizî, I-V, Beyrut, Tarihsiz.

Türk Gençliğinin Müzik Eğitimi, 27-28 Nisan 1985 Türk Kadınları Kültür Derneğinin "Türk Gençliğinin Müzik Eğitimi" konulu Sempozyumu, Kadığlu Matbaası, Ankara, 1985. 